\title{
Resolution of P-Sterogenic 1-Phenylphosphin-2-en-4-one 1-Oxide into Two Enantiomers by $(R, R)$-TADDOL and Conformational Diversity of the Phosphinenone Ring and TADDOL in the Crystal State
}

\author{
Elżbieta Łastawiecka ${ }^{1}$, Adam Włodarczyk ${ }^{1}$, Anna E. Kozioł ${ }^{2}$, Hanna Małuszyńska ${ }^{3}$ \\ and K. Michał Pietrusiewicz ${ }^{1, *(D)}$ \\ 1 Department of Organic Chemistry, Institute of Chemical Sciences, Faculty of Chemistry, \\ Maria Curie-Sklodowska University, Gliniana 33, 20-614 Lublin, Poland; \\ elzbieta.lastawiecka@mail.umcs.pl (E.Ł.); adam.wlodarczyk@mail.umcs.pl (A.W.) \\ 2 Department of Crystallography, Institute of Chemical Sciences, Faculty of Chemistry, \\ Maria Curie-Sklodowska University, Maria Curie-Sklodowska sq. 3, 20-031 Lublin, Poland, \\ anna.koziol@mail.umcs.pl \\ 3 Faculty of Physics, Adam Mickiewicz University, Umultowska 85, 61-614 Poznań, Poland; \\ hanmal@amu.edu.pl \\ * Correspondence: kazimierz.pietrusiewicz@poczta.umcs.lublin.pl
}

Citation: Łastawiecka, E.; Włodarczyk, A.; Kozioł, A.E.; Małuszyńska, H.; Pietrusiewicz, K.M. Resolution of P-Sterogenic

1-Phenylphosphin-2-en-4-one 1-Oxide into Two Enantiomers by $(R, R)$-TADDOL and Conformational Diversity of the Phosphinenone Ring and TADDOL in the Crystal State. Molecules 2021, 26, 6873. https:// doi.org/10.3390/molecules26226873

Academic Editor: Józef Drabowicz

Received: 28 October 2021

Accepted: 10 November 2021

Published: 15 November 2021

Publisher's Note: MDPI stays neutral with regard to jurisdictional claims in published maps and institutional affiliations.

Copyright: (C) 2021 by the authors. Licensee MDPI, Basel, Switzerland. This article is an open access article distributed under the terms and conditions of the Creative Commons Attribution (CC BY) license (https:// creativecommons.org/licenses/by/ $4.0 /)$.

\begin{abstract}
The resolution of racemic 1-phenylphosphin-2-en-4-one 1-oxide (2), was achieved through the fractional crystallization of its diastereomeric complexes with $(4 R, 5 R)-(-)-2,2$-dimethyl - $\alpha, \alpha, \alpha^{\prime}, \alpha^{\prime}-$ tetraphenyl-dioxolan-4,5-dimethanol ( $R, R$-TADDOL) followed by the liberation of the individual enantiomers of $\mathbf{2}$ by flash chromatography on silica gel columns. The resolution process furnished the two enantiomers of 2 of 99.1 and $99.9 \%$ e.e. at isolated yields of 62 and 59\% (counted for the single enantiomer), respectively. The absolute configurations of the two enantiomers were established by means of X-ray crystallography of their diastereomerically pure complexes, i.e., $(R)-2 \bullet R, R)$-TADDOL and $(S)-\mathbf{2} \bullet(R, R)$-TADDOL. The structural analysis revealed that in the $(R)-\mathbf{2} \bullet(R, R)$-TADDOL complex, the P-phenyl substituent occupied a pseudoequatorial position, whereas in $(S)-\mathbf{2} \bullet(R, R)$-TADDOL, it appeared in both the pseudoequatorial and the pseudoaxial positions in four symmetrically independent molecules. Concurrent conformational changes of the TADDOL molecules were best described by the observed changes of a pseudo-torsional CO...OC angle that could be considered as a possible measure of TADDOL conformation in its receptor-ligand complexes. The structural analysis of the $(R, R)$-TADDOL molecule revealed that efficiency of this compound for use as an effective resolving factor comes from its ability to flexibly fit its structure to both enantiomers of a ligand molecule, producing a rare case of resolution for both pure enantiomers with one chiral separating agent. The resolved (R)-2 was used to assign the absolute configuration of a recently described (-)-1-phenylphosphin-2-en-4-one 1-sulfide by chemical correlation. In addition, an attempted stereoretentive reduction of $(R)-2$ by $\mathrm{PhSiH}_{3}$ at $60{ }^{\circ} \mathrm{C}$ revealed an unexpectedly low barrier for P-inversion in 1-phenylphosphin-2-en-4-one.
\end{abstract}

Keywords: P-stereogenicity; phosphinanes; 1-phenylphosphin-2-en-4-one 1-oxide; six-membered carbon-phosphorus heterocycles; resolution; absolute configuration; TADDOL; optically active phosphines

\section{Introduction}

The birth and evolution of asymmetric homogeneous catalysis is strongly coupled to the development of chiral phosphorus ligands. Among them, chiral phosphacyclic ligands of different ring extensions ranging from four to seven units have been identified as the most important ones [1-5]. One of the least represented groups of phosphorus heterocyclic 
ligands are chiral six-membered carbon-phosphorus heterocycles (phosphinanes). Despite intensive research efforts over the past two decades, nonracemic phosphinanes are still relatively scarce due, most probably, to the deficiency of convenient methods enabling the synthesis of functionalized phosphinane rings that are suitable for their further structural modifications [6-17]. A collection of all of the known optically active phosphinanes grouped by their preparation methods is presented in Figure 1.

\section{A. Enantioselective desymmetrization of prochiral compounds}

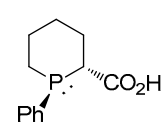

$97 \%$ e.e.

[ref. 6]

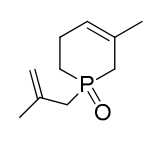

$74 \%$ e.e.

[ref. 7]

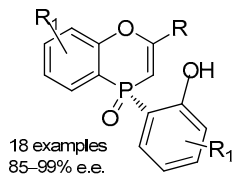

[ref. 8]

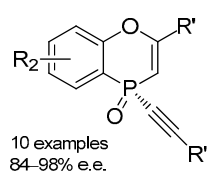

8]

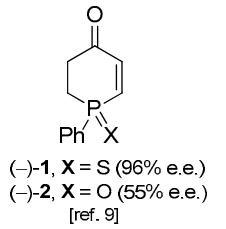

[ref. 9]

\section{B. Using a chiral auxiliary}

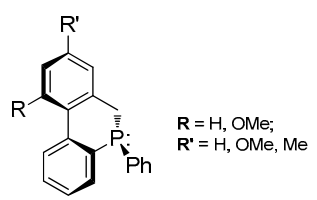

[ref 10]

\section{Ex chiral pool synthesis}

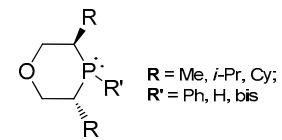

[ref. 11]

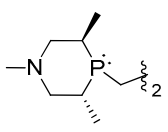

[ref. 12]

\section{Resolution of racemate}

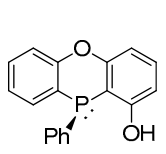

[ref 13]

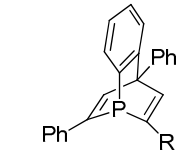

$\mathbf{R}=2-$ Naphthyl, 3 MeO- $\mathrm{C}_{6} \mathrm{H}_{4}$ 2-MeO- $\mathrm{C}_{6} \mathrm{H}_{4}, 2-\mathrm{HO}_{6} \mathrm{C}_{6} \mathrm{H}_{4}$ [ref 14]

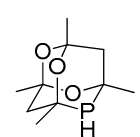

(b-Cgp)

[ref 15]
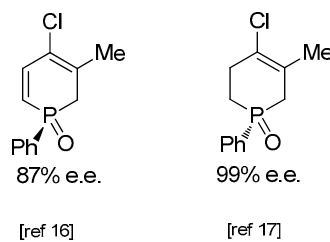

[ref 17$]$

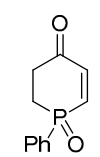

(2)

$>99 \%$ e.e.

both enantiomers

Figure 1. Reported optically active phosphinanes and type of reactions used in their synthesis.

As seen in Figure 1, one of the elegant ways in which to access nonracemic Pstereogenic phosphinanes is the use of asymmetric catalysis, which in this case, is predominantly based on the asymmetric desymmetrization of an extant phosphinane ring or on asymmetric cyclization of suitably functionalized prochiral substrates (Figure 1A) [6-9]. Other syntheses have relied on the use of a stoichiometric amount of a chiral auxiliary [10] or on chiral pool skeletal modifications (Figure 1B,C) [11,12]. Finally, the classical resolution of preformed racemic phosphinanes has also been successfully used to yield a series of optically active mono- and tricyclic phosphinanes (Figure 1D) [13-17].

Recently, we showed that optically active 1-phenylphosphin-2-en-4-one 1-sulfide (1) of $96 \%$ e.e. can be obtained via the asymmetric deprotonation of 1-phenylphosphinan4-one 1-sulfide by a chiral base followed by the IBX $\bullet \mathrm{MPO}$-promoted oxidation of the intermediate silyl enol ether [9]. In a similar desymmetrization process, the corresponding phosphinanone oxide gave the desired 1-phenylphosphin-2-en-4-one 1-oxide (2) of only $55 \%$ e.e. [9]. As such, we have decided to attempt to access the phosphinanone oxide 2 with ahigh optical purity by means of classical resolution, which is readily scalable and, in a favorable case, can even deliver both enantiomers of 2 in a single resolution run.

In this paper, we aim to achieve this through the use of $(R, R)$-TADDOL as a resolving agent, which has been found to form crystalline diastereomeric complexes of $>99 \%$ d.e. with both enantiomers of $\mathbf{2}$. We shall also present and analyze the differences in interactions and 
conformational changes of the $(R, R)$-TADDOL and phosphinenone enantiomers because the propitious crystallization made the determination of the crystal structure of the both diastereomerically pure complexes possible.

\section{Results and Discussion}

\subsection{Synthesis and Resolution of 1-Phenylphosphin-en-4-one 1-oxide (2)}

The synthesis of racemic 2 was conveniently accomplished by the $\alpha$-bromination of 1-phenylphosphinan-4-one 1-oxide (3) followed by the thermal in situ dehydrobromination of the formed 3-bromo-1-phenylphosphinan-4-one 1-oxide yielding phosphinenone rac-2 in good isolated yield (Scheme 1).<smiles>O=C1CCP(=O)(O)CC1</smiles>

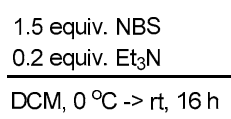

3<smiles>CCCC1CP(=O)(O)CCC1=O</smiles><smiles>O=C1C=CP(=O)(O)CC1</smiles>

$($ rac)-2

Scheme 1. Synthesis of racemic 1-phenylphosphin-2-en-4-one 1-oxide (2) by the $\alpha$-bromination/ elimination route.

Having secured a convenient method for the synthesis of gram quantities of rac-2, we then attempted to elaborate an effective method for its resolution.

Due to our previous experience, we first tried L-menthyl bromoacetate and DBTA as resolving agents. These two reagents recently allowed us to successfully resolve 1phenylphosphol-2-ene $[18,19]$ and secondary tert-butyl-phenylphosphine oxide [20], respectively, providing both enantiomers of the corresponding phosphine oxide of very high enantiomeric purity in a single resolution process in each case. Unfortunately, the attempted use of these reagents for the resolution of phosphinenone 2 did not result in the formation of complexes suitable for crystallization.

Subsequent trials with TADDOL, another resolving agent which has already successfully been utilized for the separation of racemic phospholene and phosphinane oxides by Keglevich et al. [17,21-23], finally led to the development of an efficient resolution procedure for phosphinenone oxide 2 . The developed protocol for the resolution of phosphinenone oxide 2 by $(R, R)$-TADDOL is detailed in Figure 2 .

To start the resolution process, a hot solution of the equimolar amounts of $r a c-2(9 \mathrm{~g})$ and $(R, R)$-TADDOL $(19 \mathrm{~g})$ in a mixture of ethyl acetate and chloroform was treated with hexane to result in the precipitation of a crystalline complex of $(+)-2 \bullet(R, R)$-TADDOL $(1: 1)$ within $12 \mathrm{~h}$.

The enantiomeric purity of the molecular complex $(+)-2 \bullet(R, R)$-TADDOL obtained in this way was $35 \%$ d.e. ( $69 \%$ yield). The additional recrystallization of this complex from the same mixture of solvents increased the d.e. to $50 \%$ (53\%). Due to the fact that a further increase in the diastereomeric purity proved to be difficult to achieve, after a few trials, the solvent mixture was changed to acetone/hexane, which allowed the d.e. of $(+)-2 \bullet(R, R)-$ TADDOL to increase this complex up to $>99 \%(22 \%)$.

When the mother liquor of the first crystallization was cooled down and stored in a freezer (at $-10{ }^{\circ} \mathrm{C}$ ) overnight, the other diastereomer, i.e., $(-)-2 \bullet(R, R)$-TADDOL, of $96 \%$ d.e. was obtained in a $13 \%$ yield. Another recrystallization of this complex from a mixture of ethyl acetate/chloroform/hexane at room temperature afforded a $(-)-\mathbf{2}(R, R)-$ TADDOL complex of $99.9 \%$ d.e. at an $11.5 \%$ yield. 


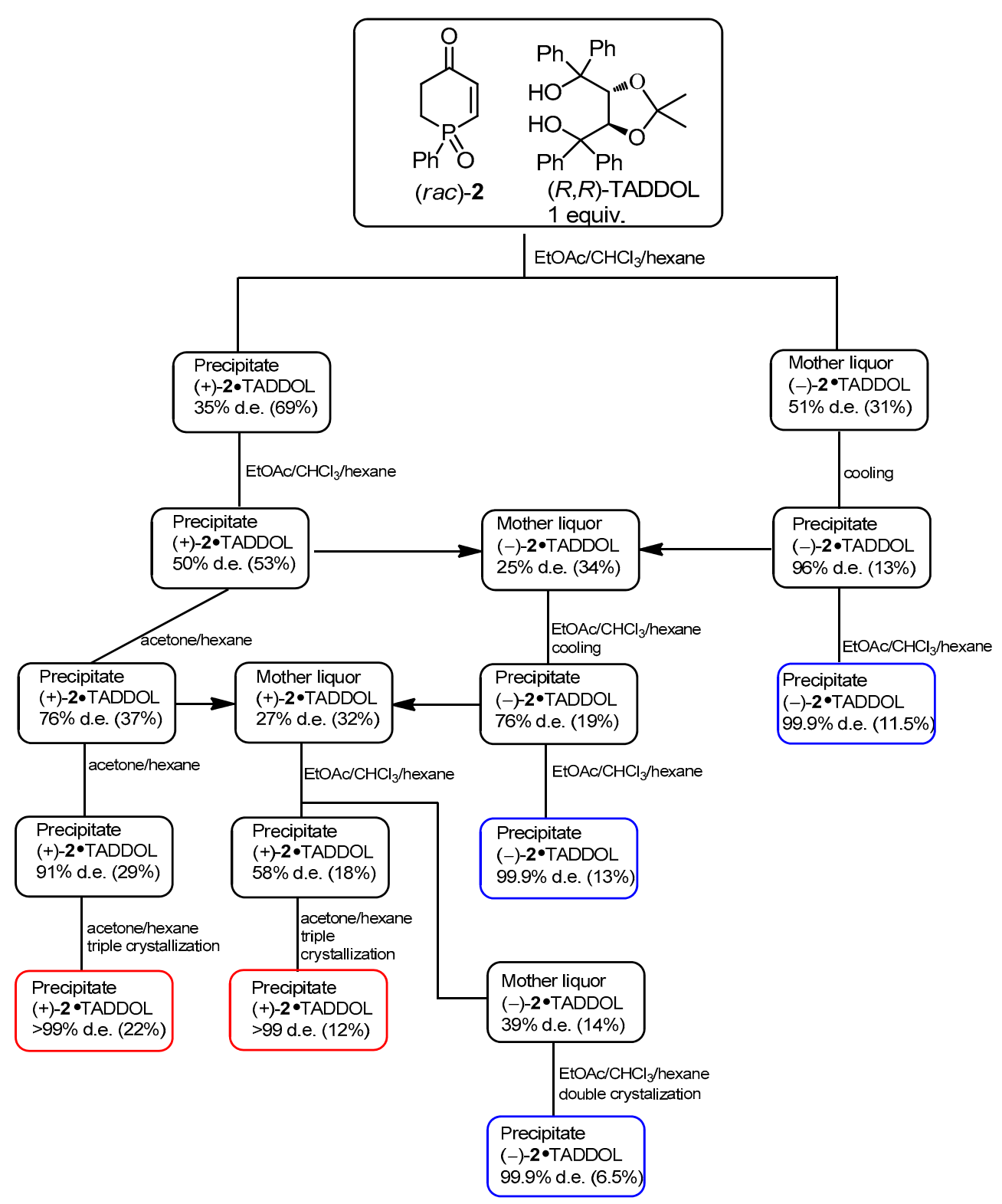

Figure 2. Gram-scale resolution of 1-phenylphosphin-en-4-one 1-oxide (2) by $(R, R)$-TADDOL.

In addition, the appropriate combination of mother liquors and continued fractional crystallizations from properly adjusted solvent mixtures, as indicated in the middle part of Figure 2, allowed us to increase the total yield of both the virtually diastereomerically pure complexes, i.e., (+)-2•(R,R)-TADDOL and $(-)-2 \bullet(R, R)-\mathrm{TADDOL}$, to 34 and 31\%, respectively.

It is also worthy of noting that the large difference in the retention times of TADDOL and phosphine oxide 2 allowed for very convenient CSP-HPLC monitoring of the d.e. (via e.e. of 2) of the separated complexes that were present in each fraction during the entire resolution process.

Separated crystals of diasteromerically pure complexes of 1-phenylphosphin-en-4-one 1-oxide (2) with $(R, R)$-TADDOL were examined by means of polarized light microscopy (Figure 3). 


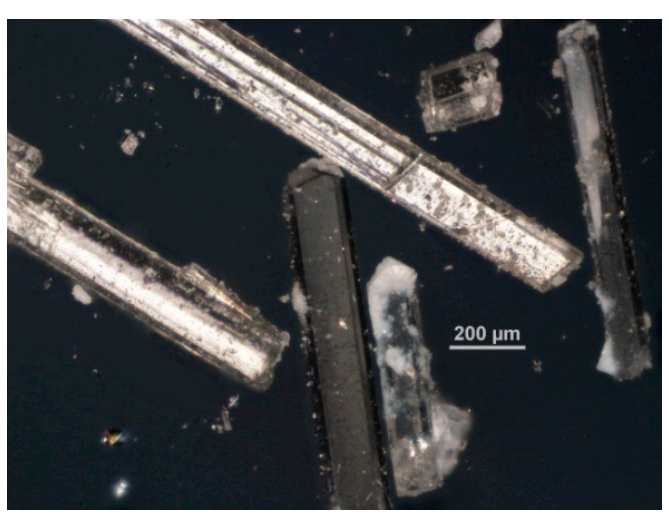

(a)

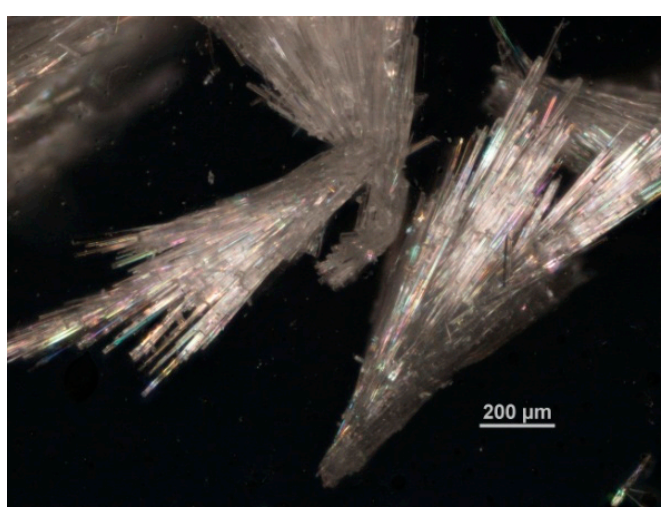

(b)

Figure 3. Images of the habit of crystals: (a) $(-)-\mathbf{2} \bullet(R, R)-\mathrm{TADDOL}$ and $(\mathbf{b})(+)-\mathbf{2} \bullet(R, R)-\mathrm{TADDOL}$ under polarized light microscopy.

Depending on the enantiomer bonded with TADDOL, the crystals take on a different morphology. The $(-)-\mathbf{2} \bullet(R, R)$-TADDOL crystals have a columnar tendency (Figure 3a), whereas needle-shaped $(+)-2 \bullet(R, R)$-TADDOL crystals are soft and form twins along the long edges (Figure $3 \mathrm{~b}$ ). Both of the crystals are colorless and transparent.

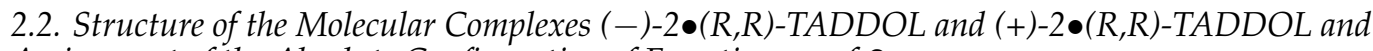
Assignment of the Absolute Configuration of Enantiomers of $\mathbf{2}$

The crystals of diastereoisomerically pure complexes of enantiomers of 2 with $(R, R)$ TADDOL were subjected to a single-crystal $X$-ray analysis to determine their structure and absolute configuration. The complexes contained $(R, R)$-TADDOL and phosphine oxide 2 in a 1:1 ratio (Figure 4), which was in accordance with the NMR studies. The molecular complex $(-)-2 \bullet(R, R)$-TADDOL crystallizes in the orthorhombic crystal system in the chiral $P 2{ }_{1} 2{ }_{1}{ }_{1}$ space group. The molecular complex $(+)-2 \bullet(R, R)$-TADDOL crystallizes in the triclinic chiral $P 1$ space group with four symmetrically independent chemical units. Thus, the stoichiometry in this crystal is $4: 4$. When the crystal unit cells have a content such as this, it enables the better fulfillment of the need for the cells to be as densely packed into the space as possible, which is achieved by conformational changes in the molecules. However, the crystal quality is poor, and two of the four phosphinenone molecules are disordered. As a result, this enantiomer of $\mathbf{2}$ is "frozen" solid in several conformations of the phosphinenone ring, and voids are observed in the crystal (Figure 5).

The absolute configuration of the phosphine oxide in the $(-)-2 \bullet(R, R)$-TADDOL complex forming the thick good quality columnar crystals with $(R, R)$-TADDOL was determined as $R$. The molecular structure of the complex and of $(R)-2$ are presented in Figure $4 \mathrm{a}, \mathrm{c}$. Accordingly, and as confirmed independently by an X-ray analysis of the second complex, the opposite enantiomer of 2 could be assigned to have the $S$ configuration at the phosphorus atom (Figure $4 \mathrm{~b}, \mathrm{~d}$ ).

In the $(S)-2 \bullet(R, R)-T A D D O L$ crystals, two of the enantiomer $(S)-\mathbf{2}$ positions are ordered (conformers I-(S)-2 and II-(S)-2), while the other two are occupied by molecules, showing a statistical disorder between the two conformations (conformers III-(S)-2 and IV-(S)-2), as depicted in Figure 6. 


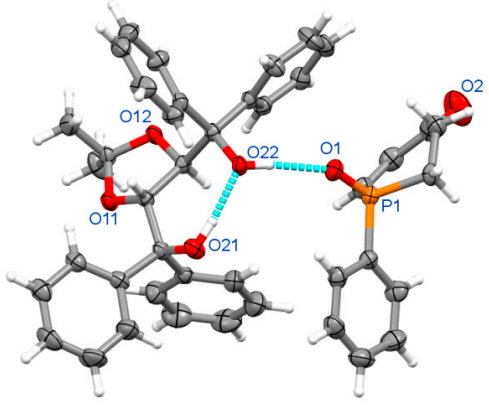

(a)

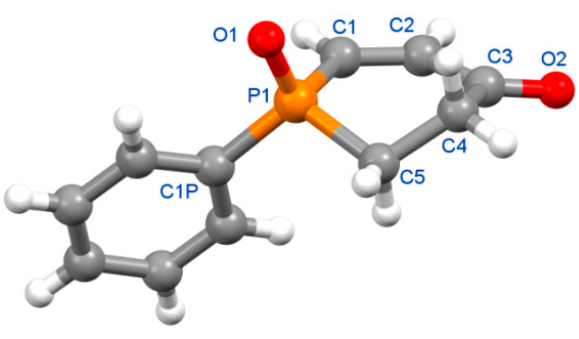

(c)

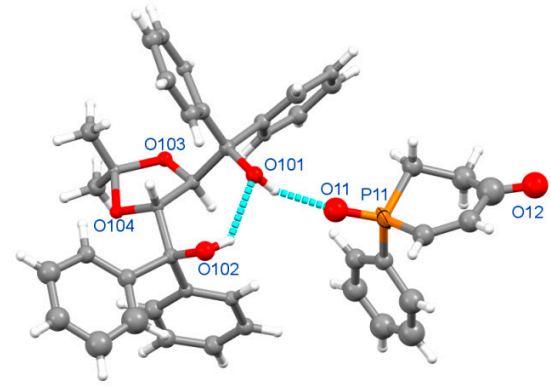

(b)

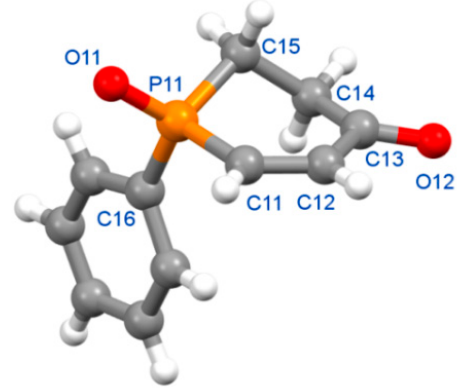

(d)

Figure 4. The 1:1 structure of the molecular complexes of $(R, R)$-TADDOL with ${ }^{\circledR}-2(\mathbf{a})$ and $(S)-2(\mathbf{b})$ with thermal ellipsoids set at 50\% probability. Perspective view of enantiomeric molecules $₫-2$ (c) and $(S)-2(d)$. Dotted blue lines indicate the O-H...O hydrogen bonds.

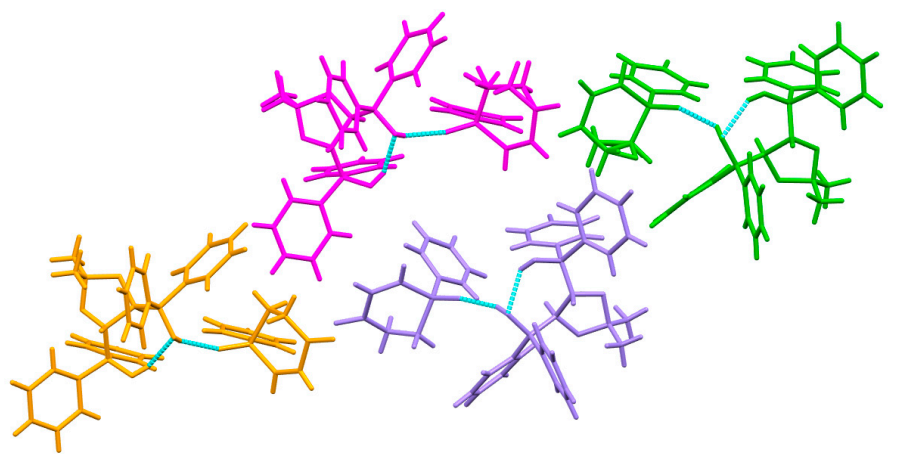

(a)

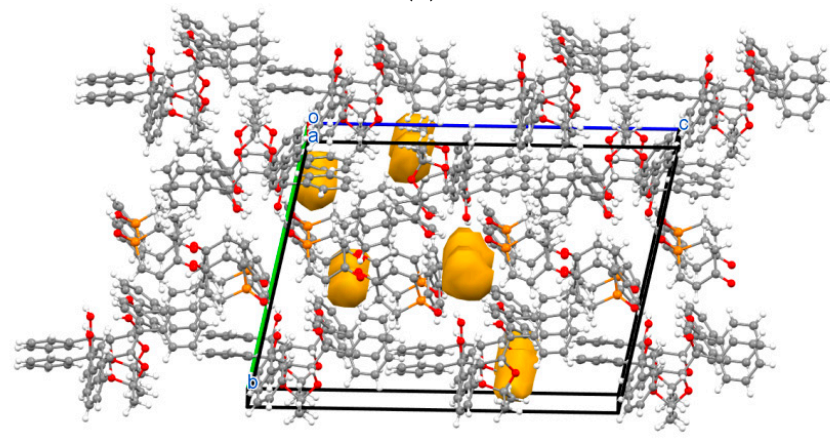

(b)

Figure 5. View of $(S)-2 \bullet(R, R)$-TADDOL: (a) the symmetrically independent part $\left(Z^{\prime}=4\right)$ of the crystal and (b) empty voids ( $1.3 \%$ of unit cell volume) in the crystal structure. 


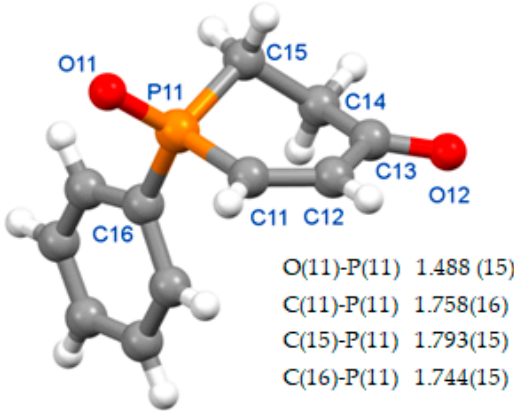

Conformer III-(S)-2

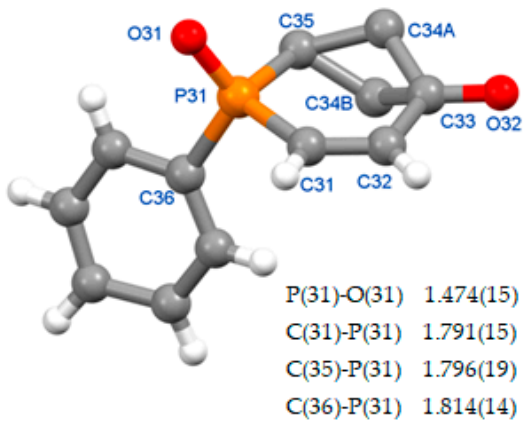

Conformer II-(S)-2

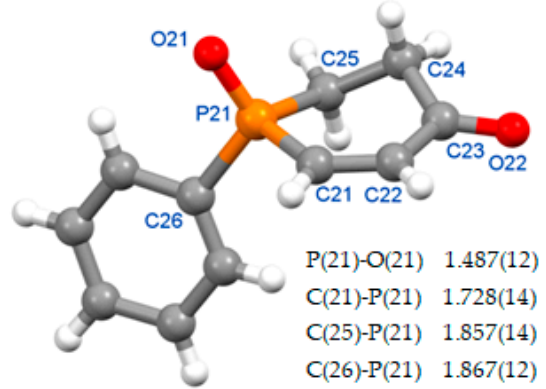

Conformer IV-(S)-2

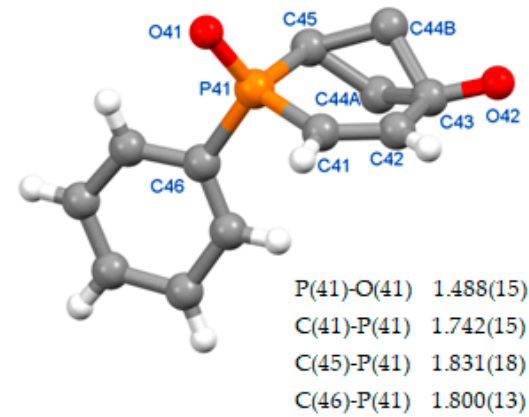

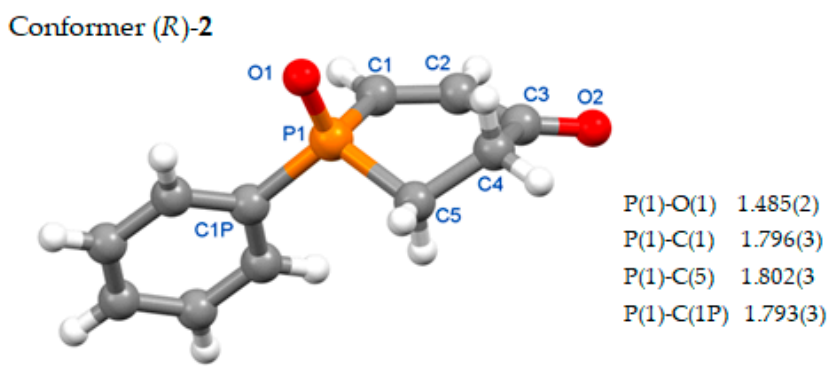

Figure 6. Perspective view of solid-state conformers observed for enantiomers $S$ and $R$ with bond lengths involving the $\mathrm{P}$ atom. The conformers III-(S)-2 and IV-(S)-2 are disordered.

The conformational variation of the six-membered phosphinenone ring takes place by changing the position of the $\mathrm{C}_{\mathrm{sp} 3}-\mathrm{C}_{\mathrm{sp} 3}$ atoms. In order to provide a complete description of the phosphinenone conformation, the specification of the endocyclic torsion angles within the rings was completed (Table 1). In the solid state, the (S)-2 molecules adopt six conformations that are in either a sofa or a half-chair formation. A ring substituent (phenyl group) at the phosphinenone unit can be either pseudoaxial or pseudoequatorial in the given conformer. The key parameter defining the orientation of the phenyl group in space are the exocyclic torsion angles, which are highlighted in green in Table 1. Interestingly, in the conformer I-(S)-2, the phenyl group adopts an energetically unpreferred pseudoaxial position [24]. Figure 7a provides the molecular fitting for all conformers of the $S$ enantiomer observed in the unit cell of its complex with $(R, R)$-TADDOL. 
Table 1. Endocyclic torsion angles $\left(^{\circ}\right)$ for phosphinenone ring and exocyclic torsion angles describing orientation of substituents on P-atom in the enantiomeric molecules ${ }^{\circledR}-\mathbf{2}$ and $(S)-\mathbf{2}$.

\begin{tabular}{|c|c|c|c|}
\hline Conformer I-(S)-2 (sofa) & angle & Conformer II-(S)-2 (half-chair) & angle \\
\hline$P(11)-C(11)=C(12)-C(13)$ & $-4(2)$ & $P(21)-C(21)=C(22)-C(23)$ & $-5(2)$ \\
\hline$C(11)=C(12)-C(13)-C(14)$ & $-2(3)$ & $C(21)=C(22)-C(23)-C(24)$ & $21(2)$ \\
\hline$C(12)-C(13)-C(14)-C(15)$ & $38(2)$ & $C(22)-C(23)-C(24)-C(25)$ & $-51(1)$ \\
\hline $\mathrm{C}(13)-\mathrm{C}(14)-\mathrm{C}(15)-\mathrm{P}(11)$ & $-65(2)$ & $\mathrm{C}(23)-\mathrm{C}(24)-\mathrm{C}(25)-\mathrm{P}(21)$ & $61(2)$ \\
\hline $\mathrm{C}(14)-\mathrm{C}(15)-\mathrm{P}(11)-\mathrm{C}(11)$ & $56(2)$ & $\mathrm{C}(24)-\mathrm{C}(25)-\mathrm{P}(21)-\mathrm{C}(21)$ & $-42(2)$ \\
\hline $\mathrm{C}(15)-\mathrm{P}(11)-\mathrm{C}(11)=\mathrm{C}(12)$ & $-21(2)$ & $C(25)-P(21)-C(21)=C(22)$ & $15(2)$ \\
\hline $\mathrm{C}(16)-\mathrm{P}(11)-\mathrm{C}(15)-\mathrm{C}(14)$ & $-59(2)$ & $\mathrm{C}(26)-\mathrm{P}(21)-\mathrm{C}(25)-\mathrm{C}(24)$ & $-153(3)$ \\
\hline $\mathrm{C}(16)-\mathrm{P}(11)-\mathrm{C}(11)=\mathrm{C}(12)$ & $92(2)$ & $\mathrm{C}(26)-\mathrm{P}(21)-\mathrm{C}(21)=\mathrm{C}(22)$ & $124(2)$ \\
\hline Conformer IIIB-(S)-2 (sofa) & angle & Conformer IIIA-(S)-2 (sofa) & angle \\
\hline$P(31)-C(31)=C(32)-C(33)$ & $2(2)$ & $\mathrm{P}(31)-\mathrm{C}(31)=\mathrm{C}(32)-\mathrm{C}(33)$ & $2(2)$ \\
\hline$C(31)=C(32)-C(33)-C(34 B)$ & $-36(2)$ & $C(31)=C(32)-C(33)-C(34 A)$ & $17(3)$ \\
\hline $\mathrm{C}(32)-\mathrm{C}(33)-\mathrm{C}(34 \mathrm{~B})-\mathrm{C}(35)$ & $73(1)$ & $C(32)-C(33)-C(34 A)-C(35)$ & $-41(3)$ \\
\hline $\mathrm{C}(33)-\mathrm{C}(34 \mathrm{~B})-\mathrm{C}(35)-\mathrm{P}(31)$ & $-66(2)$ & $\mathrm{C}(33)-\mathrm{C}(34 \mathrm{~A})-\mathrm{C}(35)-\mathrm{P}(31)$ & $44(2)$ \\
\hline $\mathrm{C}(34 \mathrm{~B})-\mathrm{C}(35)-\mathrm{P}(31)-\mathrm{C}(31)$ & $27(3)$ & $\mathrm{C}(34 \mathrm{~A})-\mathrm{C}(35)-\mathrm{P}(31)-\mathrm{C}(31)$ & $-26(3)$ \\
\hline $\mathrm{C}(35)-\mathrm{P}(31)-\mathrm{C}(31)=\mathrm{C}(32)$ & $2(2)$ & $\mathrm{C}(35)-\mathrm{P}(31)-\mathrm{C}(31)=\mathrm{C}(32)$ & $2(2)$ \\
\hline $\mathrm{C}(36)-\mathrm{P}(31)-\mathrm{C}(35)-\mathrm{C}(34 \mathrm{~B})$ & $-85(2)$ & $\mathrm{C}(36)-\mathrm{P}(31)-\mathrm{C}(35)-\mathrm{C}(34 \mathrm{~A})$ & $-138(2)$ \\
\hline $\mathrm{C}(36)-\mathrm{P}(31)-\mathrm{C}(31)=\mathrm{C}(32)$ & $113(2)$ & $\mathrm{C}(36)-\mathrm{P}(31)-\mathrm{C}(31)=\mathrm{C}(32)$ & $113(2)$ \\
\hline $\begin{array}{c}\text { Conformer IVA }(S)-2 \\
\text { (half-chair) }\end{array}$ & angle & Conformer IVB-(S)-2 (sofa) & angle \\
\hline $\mathrm{P}(41)-\mathrm{C}(41)=\mathrm{C}(42)-\mathrm{C}(43)$ & $-11(2)$ & $P(41)-C(41)=C(42)-C(43)$ & $-11(2)$ \\
\hline$C(41)=C(42)-C(43)-C(44 A)$ & $21(2)$ & $C(41)=C(42)-C(43)-C(44 B)$ & $42(3)$ \\
\hline $\mathrm{C}(42)-\mathrm{C}(43)-\mathrm{C}(44 \mathrm{~A})-\mathrm{C}(45)$ & $59(2)$ & $\mathrm{C}(42)-\mathrm{C}(43)-\mathrm{C}(44 \mathrm{~B})-\mathrm{C}(45)$ & $-67(3)$ \\
\hline $\mathrm{C}(43)-\mathrm{C}(44 \mathrm{~A})-\mathrm{C}(45)-\mathrm{P}(41)$ & $-61(2)$ & $\mathrm{C}(43)-\mathrm{C}(44 \mathrm{~B})-\mathrm{C}(45)-\mathrm{P}(41)$ & $59(3)$ \\
\hline $\mathrm{C}(44 \mathrm{~A})-\mathrm{C}(45)-\mathrm{P}(41)-\mathrm{C}(41)$ & $32(3)$ & $\mathrm{C}(44 \mathrm{~B})-\mathrm{C}(45)-\mathrm{P}(41)-\mathrm{C}(41)$ & $-29(3)$ \\
\hline $\mathrm{C}(45)-\mathrm{P}(41)-\mathrm{C}(41)=\mathrm{C}(42)$ & $5(2)$ & $\mathrm{C}(45)-\mathrm{P}(41)-\mathrm{C}(41)=\mathrm{C}(42)$ & $5(2)$ \\
\hline $\mathrm{C}(46)-\mathrm{P}(41)-\mathrm{C}(45)-\mathrm{C}(44 \mathrm{~A})$ & $-80(2)$ & $\mathrm{C}(46)-\mathrm{P}(41)-\mathrm{C}(45)-\mathrm{C}(44 \mathrm{~B})$ & $-141(2)$ \\
\hline $\mathrm{C}(46)-\mathrm{P}(41)-\mathrm{C}(41)=\mathrm{C}(42)$ & $114(2)$ & $\mathrm{C}(46)-\mathrm{P}(41)-\mathrm{C}(41)=\mathrm{C}(42)$ & $114(2)$ \\
\hline$R$ (half-chair) & angle & & \\
\hline$P(1)-C(1)=C(2)-C(3)$ & $-1.8(5)$ & & \\
\hline$C(1)=C(2)-C(3)-C(4)$ & $-8.7(5)$ & & \\
\hline$C(2)-C(3)-C(4)-C(5)$ & $44.5(4)$ & & \\
\hline$C(3)-C(4)-C(5)-P(1)$ & $-64.6(3)$ & & \\
\hline $\mathrm{C}(4)-\mathrm{C}(5)-\mathrm{P}(1)-\mathrm{C}(1)$ & $48.6(2)$ & & \\
\hline$C(5)-P(1)-C(1)=C(2)$ & $-18.1(3)$ & & \\
\hline $\mathrm{C}(1 \mathrm{P})-\mathrm{P}(1)-\mathrm{C}(5)-\mathrm{C}(4)$ & 160.1(3) & & \\
\hline$C(1 P)-P(1)-C(1)=C(2)$ & $-132.3(3)$ & & \\
\hline
\end{tabular}

(a) Fit of the tetrahedron around the $\mathrm{P}=\mathrm{O}$ Conformer I-(S)-2, II-(S)-2, III-(S)-2 and IV-(S)-2 (b) Fit of the tetrahedron around the $\mathrm{P}=\mathrm{O}$ Conformer I-(S)-2 and $(R)-2$ (c) Fit the of the $\mathrm{P}-\mathrm{C}=\mathrm{C}-\mathrm{C}$ ring fragment Conformer II-(S)-2 and $(R)-2$
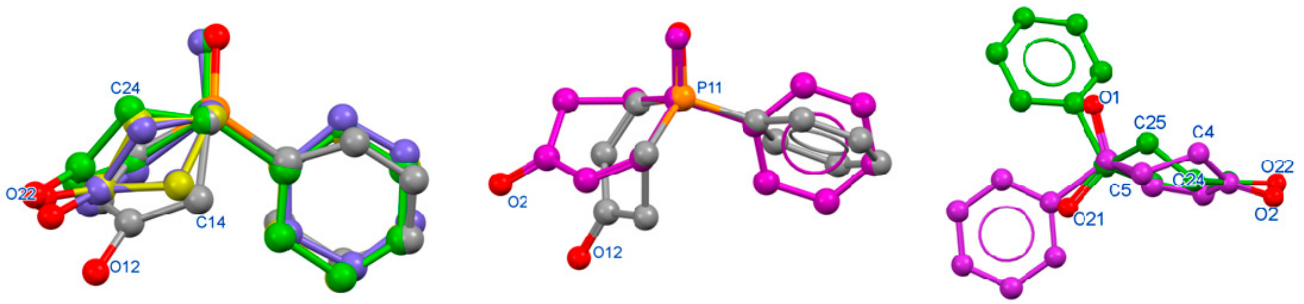

Conformer of enantiomer $(R)-2$

Conformer III-(S)-2 with disorder Conformer IV-(S)-2 with disorder

Figure 7. Molecular fitting of selected conformers. H-atoms are omitted for clarity.

The geometric data for the phosphinenone ring in molecule $(R)-2$ indicate that it adopts a half-chair conformation with the P-phenyl group in the pseudoequatorial position 
(Figure 4c). A major conformational difference in the orientation of the phenyl ring is seen for I-(S)-2 and (R)-2 (Figure 7b). The molecular fitting of conformers II-(S)-2 to $(R)-\mathbf{2}$, which both adopt the half-chair conformation, shows the opposite twisting of the $\mathrm{sp}^{3}$-hybridised carbon atoms of the phosphinenone ring (Figure 7c).

\subsection{Geometry of TADDOL Molecules and Their Intermolecular and Intramolecular Contacts}

Due to its chemical structure, TADDOL, which possesses hydroxyl groups in the vicinity of the voluminous hydrophobic parts, is able to bind the specific chemical groups of the ligand. This type of molecular receptor ligand complex can be formed with molecules with hydrogen bond acceptors, i.e., $\mathrm{C}=\mathrm{O}, \mathrm{C}=\mathrm{S}, \mathrm{CN}$, or $\mathrm{P}=\mathrm{O}$ groups, for example. Expectedly, the strongest directional interactions stabilizing the molecular complexes in the studied crystal structures are intermolecular $\mathrm{O}-\mathrm{H} . . . \mathrm{O}$ hydrogen bonds that are formed between one of the hydroxyl groups of TADDOL and the oxygen atom of $\mathrm{P}=\mathrm{O}$ function of 2 . In the TADDOL molecule, there is also an intramolecular hydrogen bond between the hydroxyl groups, which helps to fine-shape a cavity for incoming ligand molecules (Figure 4a,c, Table 2).

Table 2. Geometry of inter- and intramolecular O-H...O hydrogen bonds in molecular complexes of 2 with TADDOL acting as a hydrogen bond donor.

\begin{tabular}{|c|c|c|c|c|c|}
\hline $\begin{array}{l}\text { Acceptor } \\
\text { Molecule }\end{array}$ & D-H...A & d(D-H) (A) & d(H...A) (̊) & d(D...A) (̊̊) & $<$ (DHA) $\left(^{\circ}\right)$ \\
\hline $\mathrm{I}-(S)-2$ & $\mathrm{O}(101)-\mathrm{H}(101) \ldots \mathrm{O}(11)$ & 0.82 & 1.84 & $2.597(14)$ & 153 \\
\hline$(*)$ & $\mathrm{O}(102)-\mathrm{H}(10 \mathrm{G}) \ldots \mathrm{O}(101)$ & 0.82 & 2.04 & $2.687(13)$ & 136 \\
\hline II- $(S)-2$ & $\mathrm{O}(202)-\mathrm{H}(20 \mathrm{G}) \ldots \mathrm{O}(21)$ & 0.82 & 1.94 & 2.601(13) & 137 \\
\hline$(*)$ & $\mathrm{O}(201)-\mathrm{H}(201) \ldots \mathrm{O}(202)$ & 0.82 & 2 & $2.635(12)$ & 134 \\
\hline III-(S)-2 & $\mathrm{O}(301)-\mathrm{H}(301) \ldots \mathrm{O}(31)$ & 0.82 & 2 & $2.681(15)$ & 140 \\
\hline$(*)$ & $\mathrm{O}(302)-\mathrm{H}(30 \mathrm{G}) \ldots \mathrm{O}(301)$ & 0.82 & 2.05 & $2.670(13)$ & 132 \\
\hline IV-(S)-2 & $\mathrm{O}(401)-\mathrm{H}(401) \ldots \mathrm{O}(41)$ & 0.82 & 1.97 & $2.617(13)$ & 135 \\
\hline$(*)$ & $\mathrm{O}(402)-\mathrm{H}(40 \mathrm{G}) \ldots \mathrm{O}(401)$ & 0.82 & 2.03 & $2.696(12)$ & 138 \\
\hline (B-2 & $\mathrm{O}(22)-\mathrm{H}(11) \ldots \mathrm{O}(1)$ & 0.84 & 1.83 & $2.659(5)$ & 171 \\
\hline$(*)$ & $\mathrm{O}(21)-\mathrm{H}(21) \ldots \mathrm{O}(22)$ & 0.9 & 1.75 & $2.645(4)$ & 173 \\
\hline
\end{tabular}

$\left(^{*}\right)$-intramolecular hydrogen bond in TADDOL.

Hirshfeld surfaces and their respective fingerprints [25] were calculated to illustrate the differences in the interactions involving the enantiomers $(R)-2$ and (S)-2 (Figures 8 and 9). The dominant interactions are H...H contacts $(72-79 \%)$, which is obvious when taking into account the chemical structure of the molecules. It should be emphasized that the range and directionality of the interactions of each $\mathrm{S}$ conformer are significantly different and are different from those of the $R$ enantiomer.

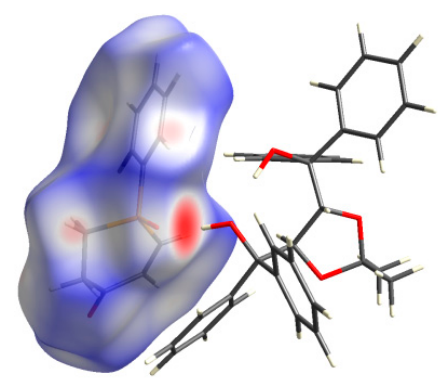

Enantiomer ${ }^{\circledR}-\mathbf{2}$ in TADDOL complex

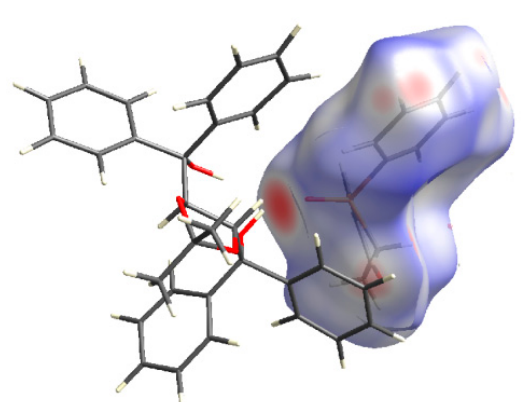

Conformer II-(S)-2 in TADDOL complex

Figure 8. The Hirshfeld surfaces $\left(\mathrm{d}_{\text {norm }}\right)$ for molecules $(R)-2$ and II-(S)-2. The atoms with contacts shorter than the van der Waals radii are marked in red. 
(R)-2 (all atoms)

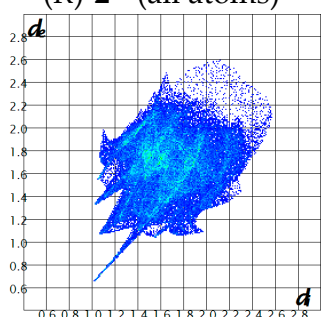

$\mathrm{I}-(S)-2$ (all atoms)

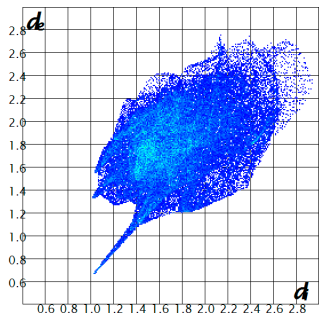

H $\quad 77.7 \%$

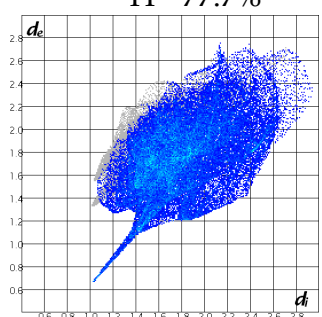

H $\quad 79.3 \%$
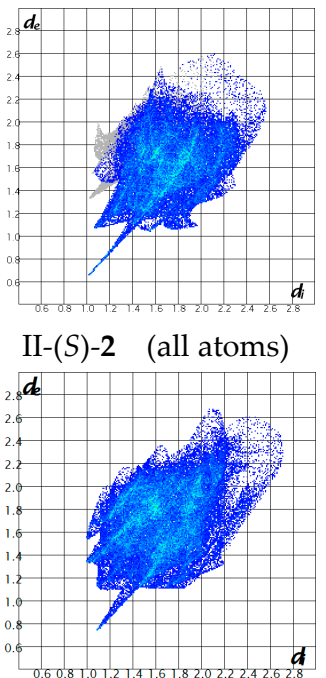

H $\quad 72.7 \%$

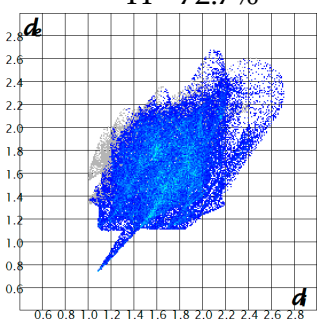

O $7.9 \%$
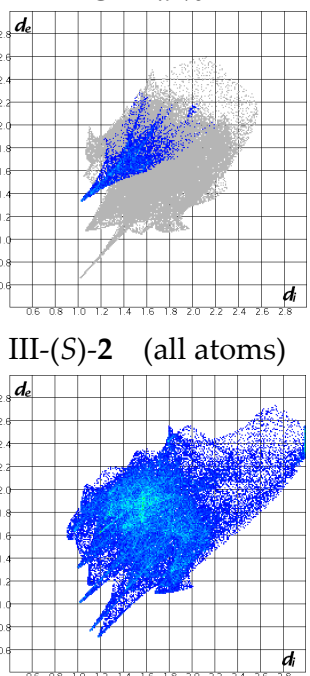

H $\quad 76.4 \%$

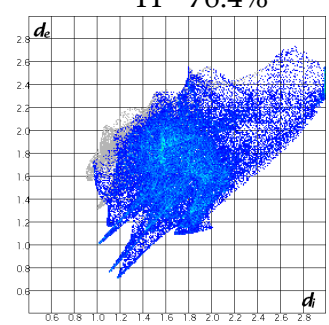

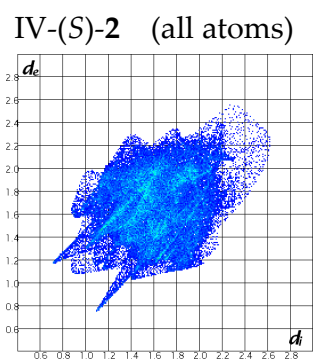

H $73.8 \%$

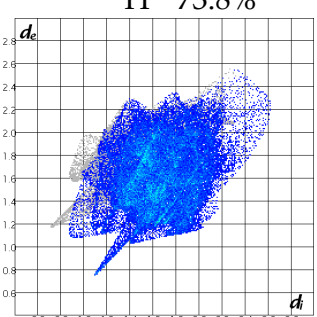

Figure 9. Fingerprints for intermolecular contacts involving enantiomeric ( $R$ )-2 and (S)-2 molecules.

The Hirshfeld surfaces calculated for $(R, R)$-TADDOL (Figure 10) indicate that the hydroxyl group is a part of the O-H...O synthon.

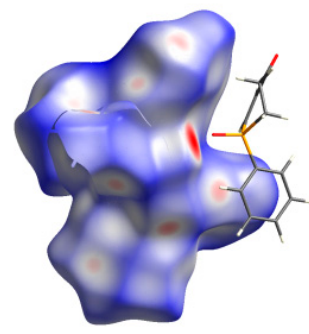

(a) $(R, R)-$ TADDOL in complex with $(R)-2$

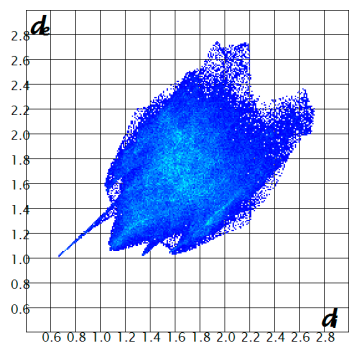

(c) Fingerprints for $(R, R)$-TADDOL in complex with $(R)-2$

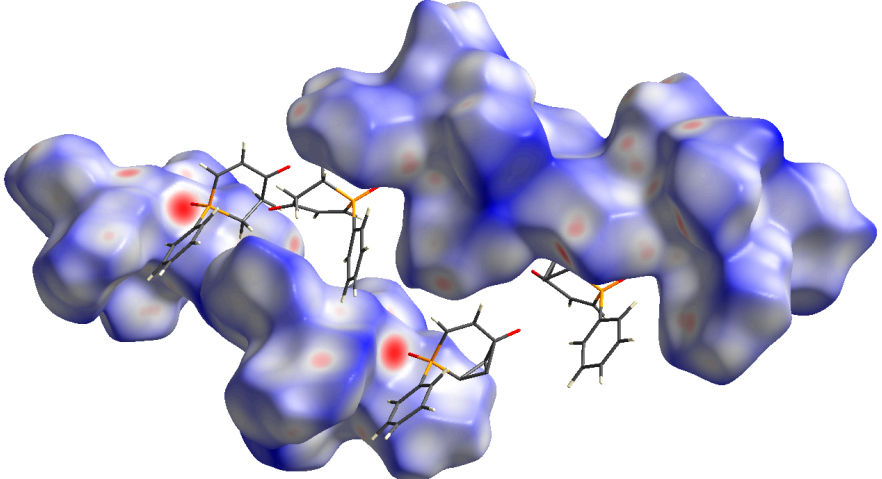

(b) $(R, R)$-TADDOL in complex with $(S)-2$

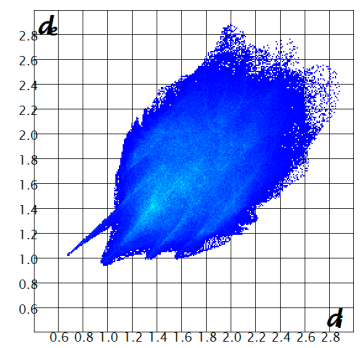

Figure 10. The Hirshfeld surfaces $\left(d_{\text {norm }}\right)$ for TADDOL molecules in complexes $(\mathbf{a}, \mathbf{b})$. The atoms with contacts shorter than the van der Waals radii are marked in red. Fingerprints for TADDOL interactions (c,d). 
The formation of a molecular complex of the receptor $\bullet$ ligand type, viz. the TADDOL• enantiomeric molecule, is possible due to a cavity formed inside the receptor molecule. The shape of this docking site can be changed by the rotation of the diphenyl- hydroxymethyl groups. To follow such conformational changes in the TADDOL molecule, in its complexes, we have chosen a pseudo-torsion angle C-O...O-C as a suitable geometric parameter (Figure 11).

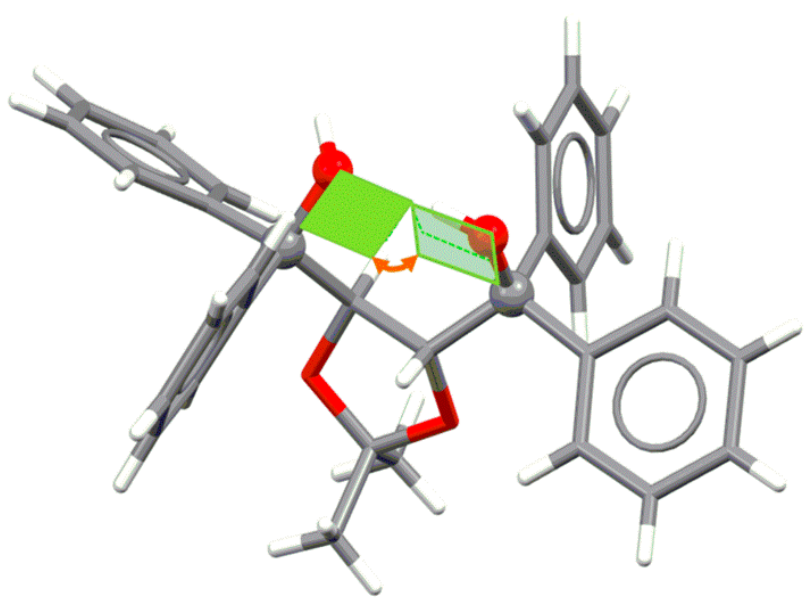

Figure 11. The definition of the C-O...O-C pseudo-torsion angle in TADDOL molecule.

As can be seen in Table 3, in the complexes described in this paper, the pseudo-torsion angles (Figure 11) were found to be in a rather narrow range of $14-21^{\circ}$, not indicating any really significant conformational changes in the TADDOL molecules. In order to compare the obtained results with the literature data, we did a structural data search in the Cambridge Structural Database (CSD ver. 5.42) for the occurrence of $(R, R)$-TADDOL complexes with various ligands. To our surprise, the search revealed only 46 determined crystal structures despite the fact that TADDOL is a rather frequently used resolving agent (see SI, for the results of the CSD search). Moreover, 11 crystals were solvated, and among the rest of the described structures, the crystals of a pair of diastereomeric complexes were only examined in two cases [26,27]. In addition, for one of them, the structure of a complex containing racemate was also determined.

Table 3. The values of C-O... O-C angle in TADDOL observed in selected receptor $\bullet$ ligand complexes. ${ }^{*}$ - crystal structures with $\mathrm{Z}^{\prime}=2$.

\begin{tabular}{|c|c|c|c|c|}
\hline \multicolumn{2}{|c|}{ This Paper } & \multicolumn{2}{|c|}{ Literature } & \multirow{2}{*}{ Ref. } \\
\hline Conformer/Enantiomer & {$\left[^{\circ}\right]$} & CSD REFCOD & {$\left[{ }^{\circ}\right]$} & \\
\hline TADDOL $\cdot \mathbf{I}-(S)-\mathbf{2}$ & 19 & VIWFIR & 15 & [22] \\
\hline TADDOL· II-(S)-2 & 14 & HIBBUQ & 24 & [21] \\
\hline TADDOL $\cdot$ III- $(S)-2$ & 14 & $\operatorname{CUXKUC~}(S)$ & 44 & [25] \\
\hline TADDOL $\cdot$ IV-(S)-2 & 17 & CUXMIS ® & 30,5 & [25] $\left(^{*}\right)$ \\
\hline \multirow[t]{3}{*}{ TADDOL· $®-2$} & 21 & CUXLAJ (rac) & 32,3 & [25] $\left({ }^{*}\right)$ \\
\hline & & QERDEW $(S)$ & 48 & [26] \\
\hline & & QERDIA $\AA(2: 1)$ & 10,12 & [26] \\
\hline
\end{tabular}

An analysis of the collected structural data indicates that formation of a stable receptor ligand system in the case of crystalline complexes of these diastereomeric pairs is accompanied by conformational changes in the TADDOL molecules. The values of the C-O...O-C pseudo-torsion angle in complexes formed with the $R$ and with the $S$ enantiomer can differ even by $38^{\circ}$ within a pair (Table 3 ). As is also suggested by the sparse structural data that are available, another way to form stable receptor ligand complexes is to increase 
the number of molecules in the asymmetric part of the cell (CUXKUC \& CUXMIS) or to change the stoichiometry of the components (QERDEW \& QERDIA).

Literature data for complexes with phosphine oxides only refer to two phospholene compounds (VIWFIR, HIBBUQ) [21,22]. In their fractional crystallization with TADDOL, crystals with only one enantiomer were formed, while the other remained in the mother liquor. The main difference between phospholene and phosphinenone is conformational rigidity. Apparently, in our study, a considerable conformational flexibility of the phosphinenone cyclic skeleton allowed the "mismatched" enantiomer to assume four conformations in order to achieve better fitting to the asymmetric environment at the docking point and to the crystal lattice. Altogether, it enabled the effective formation of a crystalline complex with this enantiomer, with only minor conformational changes in the TADDOL molecule.

\subsection{Liberation of Enantiomers of 1-Phenyl-phosphin-2-en-4-one 1-oxide (2) from Their Diastereomerically Pure Complexes with $(R, R)-T A D D O L$}

Finally, the enantiomers of 1-phenyl-phosphinenone 1-oxide (2) were liberated from the diastereomerically pure complexes without any loss of optical purity at $\mathrm{P}$ by flash chromatography on silica gel (Figure 12). In this way, the enantiomers $(S)-2(99.1 \%$ e.e.) and $(R)-2(99.9 \%$ e.e.) were obtained at overall yields of 62 and 59\%, respectively, (based on one enantiomer), and the $(R, R)$-TADDOL was also recovered in a nearly quantitative yield.

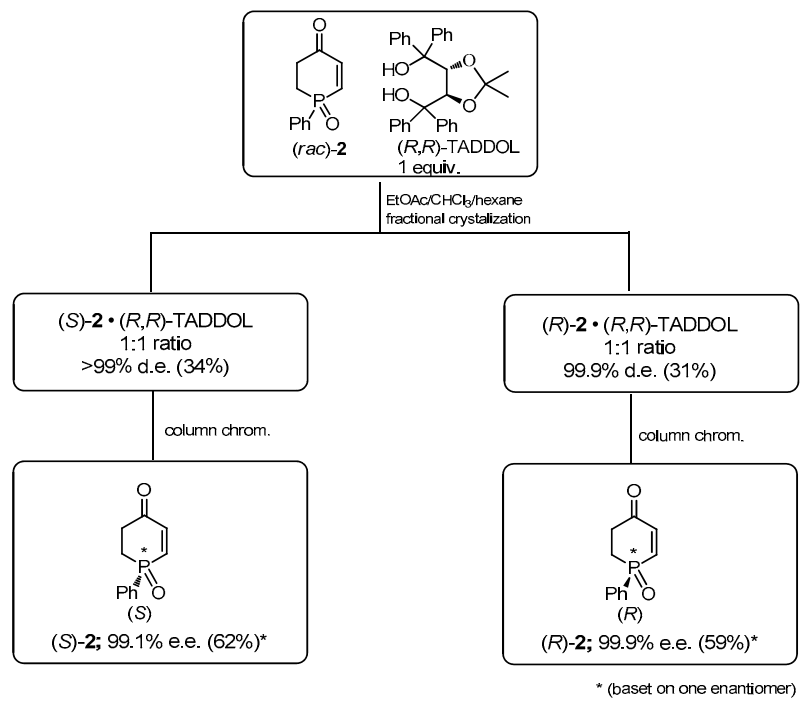

(a)
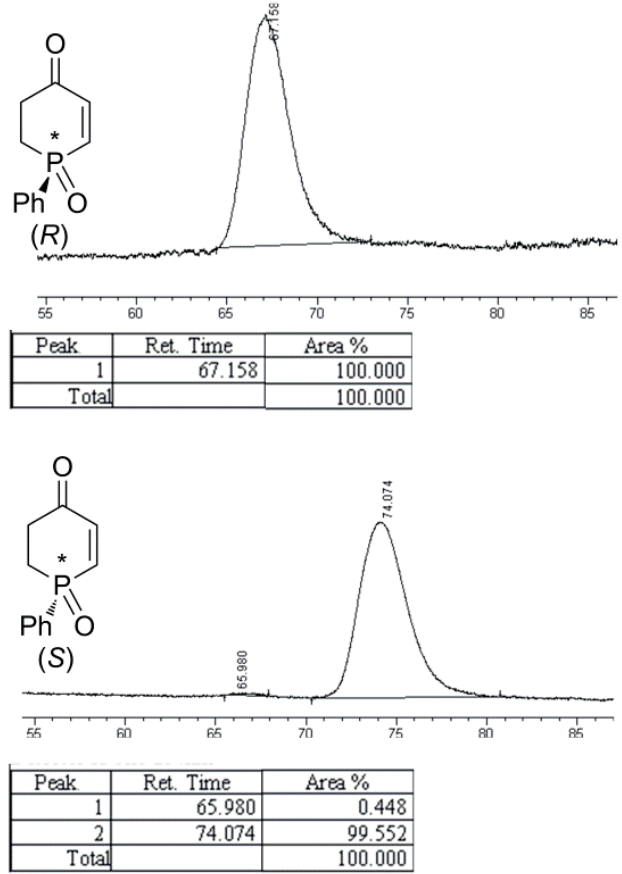

(b)

Figure 12. (a) Liberation of the enantiomers of phosphin-2-en-4-one 2 on silica gel columns; (b) copies of CSP-HPLC traces of $(R)-2$ and (S)-2 (CHIRALCEL-OD-H).

2.5. Determination of the Absolute Configuration of 1-Phenylphosphin-2-en-4-one 1-Sulfide (1) by Chemical Correlation

As already mentioned above, we have previously obtained optically active 1-phenyl phosphin-2-en-4-one 1-sulfide (-)-(1) of $96 \%$ enantiomeric purity by means of the catalytic desymmetrization of prochiral 1-phenylphosphinan-4-one 1-sulfide. However, due to the fact that it was an oil, its absolute configuration could not be readily determined. As we now have access to the resolved enantiomers of oxide 2 of the known configuration, we decided to carry out a chemical correlation of phosphinenone sulfide (-)-1 with the resolved $(-)-(R)-2$. We chose to base the correlation on a stereoretentive reduction of 
phosphinenone oxide $(R)-2$ by phenylsilane [28] followed by a similarly stereoretentive oxidation of the resulting phosphine 4 by elemental sulfur [29] to obtain phosphinenone sulfide $(R)-\mathbf{1}$ (Scheme 2).<smiles>O=C1C=CP(=O)(c2ccccc2)CC1</smiles>

$(R)-(-)-2$

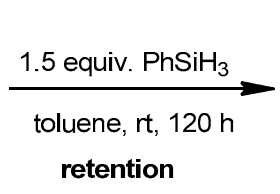

Scheme 2. Chemical correlation of phosphinenone oxide ${ }^{\circledR}-\mathbf{2}$ with phosphinenone sulfide (-)-1.

To our surprise, carrying out the reduction of $(R)-\mathbf{1}$ under standard moderate conditions (heating at $60{ }^{\circ} \mathrm{C}$ for $48 \mathrm{~h}$ ) resulted in obtaining a racemic phosphine 4 . We assumed that the observed racemization could be related to an unexpectedly low inversion barrier of the produced phosphine 4 [30]. Indeed, lowering the reduction temperature to $40{ }^{\circ} \mathrm{C}$ slowed down the inversion process as expected, but the partial erosion of the original $99.9 \%$ enantiopurity down to $41 \%$ e.e. was still observed. A full retention of the enantiomeric purity was finally achieved by running the reduction at room temperature, albeit at the cost of a very low yield ( $>99 \%$ e.e., $11 \%$ yield after 5 days). Then, to the crude reaction mixture containing enantiopure, phosphine 4 that had been obtained in this way was added to elemental sulfur to complete the correlation process (Scheme 2). A CSP-HPLC (CHIRALCEL OJ-H column) analysis of the produced phosphinenone sulfide $(R)-\mathbf{1}$ and the $(-)-1$ previously obtained had revealed that the two phosphine sulfides were of the same configuration (Figure 13, top two traces). An additional run for racemic phosphinenone sulfide 1 (Figure 13, bottom trace) further corroborated this assignment. Therefore, the absolute configuration of the previously synthesized (-)-1 could be unequivocally assigned as $R$.

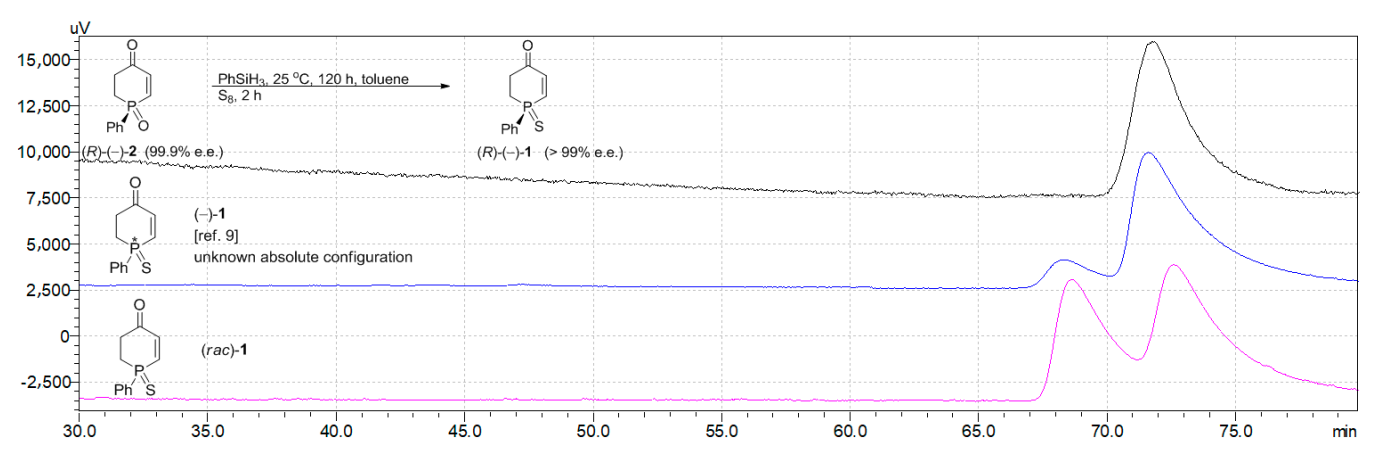

Figure 13. Assignment of the absolute configurations by chemical correlation. Copies of CSP-HPLC traces of-rac-1;-(-)-1;- sulfide $\mathbf{1}$ from the correlation experiment.

\section{Materials and Methods}

\subsection{General Information}

Reagents were purchased from commercial suppliers and were used without further purification. All of the the reactions were performed in a flame dried, argon-filled glassware. Only dry, air-free solvents were used for the reactions: THF and toluene were dried over sodium/benzophenone ketyl; DCM was dried over $\mathrm{P}_{4} \mathrm{O}_{10}$. Solvents for chromatography and extraction were commercially available and used as received without further purification. Solvents for crystallization and $\mathrm{NEt}_{3}$ were distilled once before the use. The 1-phenyl-phosphinan-4-one 1-oxide [9] and TADDOL [31] were prepared according to procedures outlined in the literature.

The NMR spectra was recorded with a Bruker Ascend $(500 \mathrm{MHz})$ spectrometer in $\mathrm{CDCl}_{3}$ as a solvent at room temperature unless otherwise noted. Chemical shifts $(\delta)$ are 
given in ppm relative to tetramethylsilane $\left({ }^{1} \mathrm{H}\right)$, residual $\mathrm{CHCl}_{3}\left({ }^{13} \mathrm{C}\right)$ or external $85 \%$ $\mathrm{H}_{3} \mathrm{PO}_{4}\left({ }^{31} \mathrm{P}\right)$ as a reference. Coupling constants $(J)$ are in Hz. The following abbreviations of signal patterns are as follows: s (singlet), $d$ (doublet), $t$ (triplet), $q$ (quartet), $m$ (multiplet), and br (broad). High-resolution mass spectrometry analyses were obtained on a Shimadzu LCMS IT-TOF spectrometer. Elementary analyses were performed on a PerkinElmer CHN 2400 analyzer. Melting points were determined on a Büchi Melting Point M-560 in a capillary tube and are uncorrected. Mass spectra were recorded with a GC-MS spectrometer working in electron ionization (EI) mode. Chiral HPLC analysis was performed on a Shimadzu HPLC using CHIRALCEL ${ }^{\circledR}$ columns. Optical rotations were measured on a PerkinElmer 341LC spectrometer using a $1 \mathrm{~mL}$ cell with a $10 \mathrm{~cm}$ path length at ambient temperature and are reported as follows: $[\alpha]_{\mathrm{D}}^{20}(\mathrm{c} \mathrm{g} / 100 \mathrm{~mL}$, solvent). Thin layer chromatography (TLC) was performed with precoated silica gel plates (Kieselgel 60, F254 on aluminum sheet, Merck) and visualized by potassium permanganate $\left(\mathrm{KMnO}_{4}\right)$ stain or through exposure to iodine vapor. All separations and purifications by column chromatography were conducted using gel 60 (230-400 mesh), unless noted otherwise. X-ray crystallography: the single crystal diffraction data were collected with an Xcalibur Gemini diffractometer (Oxford Diffraction) using graphite monochromated $\mathrm{CuK} \alpha$ radiation for the ${ }^{\circledR}-2 \bullet T A D D O L$ crystal and MoK $\alpha$ for the (S)-2•TADDOL complex. The CrysAlisPro program system [32] was used for data collection, cell refinement, and data reduction. The intensities were corrected for Lorentz and polarization effects, and a multi-scan absorption correction was applied. Crystal structure was solved by direct methods using the SHELXS-86 and SHELXT programs and refined by the full-matrix least squares method on $F^{2}$ using the SHELXL-97 program [33-35]. The experimental details and final atomic parameters for the analyzed crystals were deposited into the Cambridge Crystallographic Data Centre as Supplementary Material.

\subsection{Synthesis and Resolution of 1-Phenylphosphin-2-en-4-one 1-Oxide (2)}

\subsubsection{Synthesis of (rac)-1-Phenylphosphin-2-en-4-one 1-Oxide ( $\mathrm{rac}-2)$}

To a mixture of 1-phenylphosphinan-4-one 1-oxide (3) $(1 \mathrm{~g}, 5 \mathrm{mmol})$ and $\mathrm{Et}_{3} \mathrm{~N}(0.14 \mathrm{~mL}$, $1 \mathrm{mmol})$ in DCM $(100 \mathrm{~mL})$ placed in a flame-dried Schlenk tube $(200 \mathrm{~mL})$ equipped with a magnetic stirring bar, $1.35 \mathrm{~g}(7.5 \mathrm{mmol})$ of NBS at $0{ }^{\circ} \mathrm{C}$ (ice/water bath) was added portionwise. Then, the resulting reaction mixture was allowed to warm to room temperature and was stirred for further $16 \mathrm{~h}$ at that temperature. After that time, the reaction mixture was warmed up to $60^{\circ} \mathrm{C}$ (heating mantle) for $30 \mathrm{~min}$ to complete the quantitative elimination of $\mathrm{HBr}$ from the intermediate bromo ketone. The evaporation of the reaction mixture produced crude phosphinenone 2 . The crude product was purified on a silica gel column using DCM/THF = 10:1 as the eluent to produced 1-phenylphosphin-2-en-4-one 1-oxide (rac-2) as colorless crystals at a64\% yield $(0.66 \mathrm{~g}, 3.2 \mathrm{mmol}), \mathrm{m} . \mathrm{p} .=106.5-107.3^{\circ} \mathrm{C}$, $\mathrm{R}_{\mathrm{f}}=0.33\left(\mathrm{CHCl}_{3} / \mathrm{THF}=10: 1\right) .{ }^{1} \mathrm{H}$ NMR $\left(500 \mathrm{MHz}, \mathrm{CDCl}_{3}\right): \delta 7.79-7.74(\mathrm{~m}, 2 \mathrm{H}), 7.65-7.60$ $(\mathrm{m}, 1 \mathrm{H}), 7.58-7.48(\mathrm{~m}, 2 \mathrm{H}), 7.10-7.04(\mathrm{~m}, 1 \mathrm{H}), 6.73(\mathrm{dd}, J=13.6$ and $23.0 \mathrm{~Hz}, 1 \mathrm{H}), 3.15(\mathrm{~s}$, $1 \mathrm{H}), 2.85-2.73(\mathrm{~m}, 1 \mathrm{H}), 2.62-2.51(\mathrm{~m}, 1 \mathrm{H}), 2.49-2.40(\mathrm{~m}, 1 \mathrm{H}) .{ }^{13} \mathrm{C} \mathrm{NMR}\left(126 \mathrm{MHz}, \mathrm{CDCl}_{3}\right): \delta$ $196.1(\mathrm{~d}, J=14.5 \mathrm{~Hz}, \mathrm{C}=\mathrm{O}), 142.6(\mathrm{C} 3), 138.2(\mathrm{~d}, J=83.6 \mathrm{~Hz}, \mathrm{C} 2), 132.9\left(\mathrm{~d}, J=2.7 \mathrm{~Hz}, \mathrm{C}_{\text {para }}\right)$, $130.6\left(\mathrm{~d}, J=10.9 \mathrm{~Hz}, \mathrm{C}_{\text {ortho }}\right), 129.9\left(\mathrm{~d}, J=105.4 \mathrm{~Hz}, \mathrm{C}_{\mathrm{ipso}}\right), 129.2$ (d, J = $\left.12.7 \mathrm{~Hz}, \mathrm{C}_{\text {meta }}\right), 33.8$ $(\mathrm{d}, J=6.4 \mathrm{~Hz}, \mathrm{C} 5), 26.5(\mathrm{~d}, J=70.8 \mathrm{~Hz}, \mathrm{C} 6) .{ }^{31} \mathrm{P} \mathrm{NMR}\left(202 \mathrm{MHz}, \mathrm{CDCl}_{3}\right): \delta 16.9 \mathrm{ppm}$. GCMS (EI, $70 \mathrm{eV}) \mathrm{m} / z=178.00$ (33), 150.00 (19), 132.05 (10), 131.05 (100), 124.00 (24), 103.05 (14). Anal. Calcd for $\mathrm{C}_{11} \mathrm{H}_{11} \mathrm{O}_{2} \mathrm{P}: \mathrm{C}, 64.08 ; \mathrm{H}, 5.38$. Found: $\mathrm{C}, 64.01 ; \mathrm{H}, 5.24$.

\subsubsection{Resolution of rac-2 Using $(R, R)$-TADDOL}

To $9 \mathrm{~g}$ (43.7 mmol) of 1-phenylphosphin-2-en-4-one 1-oxide (rac-2) and $19 \mathrm{~g}$ of $(R, R)$ TADDOL in $30 \mathrm{~mL}$ of hot $\mathrm{CHCl}_{3}$ and $20 \mathrm{~mL}$ of EtOAc, $75 \mathrm{~mL}$ of hexane were added. After the addition, coloreless crystals started to appear. The next $50 \mathrm{~mL}$ of hexane was added in two portions during following $4 \mathrm{~h}$ of the crystallization process. After $12 \mathrm{~h}$, the crystals were separated by filtration to produce $20 \mathrm{~g}(69 \%)$ of complex $(S)-2 \bullet(R, R)$-TADDOL of $35 \%$ d.e. This complex was further purified by one recrystallization from a mixture of 
$\mathrm{CHCl}_{3} /$ EtOAc/hexane $(30 / 20 / 100 \mathrm{~mL})$ to afford the complex $(S)-2 \bullet(R, R)-$ TADDOL at a $53 \%$ yield and of $50 \%$ d.e. The next four recrystallizations of this complex from acetone/hexane $(50 / 200 \mathrm{~mL})$ allowed us to obtain the $(S)-2 \bullet(R, R)-$ TADDOL complex at $99.9 \%$ d.e. and at a $22 \%$ yield. To obtain the opposite enantiomer of 1-phenyl-phosphinenone 1-oxide (2), the mother liquor of the first crystallization was cooled down and stored in a freezer $\left(\right.$ at $-10{ }^{\circ} \mathrm{C}$ ) for one night. During that time, the formation of $(R)-2 \bullet(R, R)$-TADDOL of $96 \%$ d.e. at a $13 \%$ yield was observed. The complex was further purified by one recrystallization from a mixture of $\mathrm{CHCl}_{3} /$ EtOAc/hexane $(10 / 10 / 70 \mathrm{~mL})$ at room temperature to afford the complex $(R)-2 \bullet(R, R)$-TADDOL at $99.9 \%$ d.e. and at an $11.5 \%$ yield. The appropriate combination of mother liquors and the proper recrystallization of the selected solvent mixtures (see middle part of Figure 2) provided additional portions of diastereoisomerically pure $(S)-\mathbf{2} \bullet(R, R)$-TADDOL and $(R)-\mathbf{2} \bullet(R, R)$-TADDOL complexes, which increased the total yield for both the diastereoisomerically pure molecular complexes up to $34 \%$ and $31 \%$, respectively. Column chromatography on silica gel $\left(\mathrm{CHCl}_{3} / \mathrm{THF}=10 / 1\right)$ of the complexes furnished $2.65 \mathrm{~g}$ (12.9 mmol, 59\% (based on one enantiomer)) of the enantiomerically

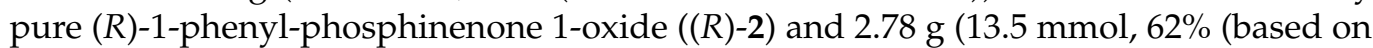
one enantiomer)) of the $>99 \%$ enantiomerically pure $(S)$-1-phenyl-phosphinenone 1-oxide $((S)-2)$. Importantly, the $(R, R)$-TADDOL that was quantitatively liberated in the same chromatographic isolation process was unaffected and could be recycled.

$(R)-2 \bullet(R, R)-T A D D O L$ complex; colorless crystals; m.p. = $159.6-160.7{ }^{\circ} \mathrm{C}$; diastereomeric excess: $>99 \%\left([\alpha]_{\mathrm{D}}^{20}=-128.8\left(\mathrm{c} 1.1, \mathrm{CHCl}_{3}\right)\right)$; CSP-HPLC conditions: CHIRALCEL OD-H, hexane $/ 2$-propanol $=90: 10,0.5 \mathrm{~mL} / \mathrm{min}$, retention time [for $\left.{ }^{\circledR}-2\right]=66.6 \mathrm{~min}$; Anal. Calcd for $\mathrm{C}_{42} \mathrm{H}_{41} \mathrm{O}_{6} \mathrm{P}: \mathrm{C}, 74.98 ; \mathrm{H}, 6.14$; Found: C, 74.79; $\mathrm{H}, 6.17$.

Crystal data: formula $\mathrm{C}_{42} \mathrm{H}_{41} \mathrm{O}_{6} \mathrm{P}, \mathrm{M}_{\mathrm{W}}=672.72$, crystal system orthorhombic, space group $P 2{ }_{1} 2_{1} 2_{1}$. Unit cell dimensions: $a=9.3684(4) \AA, b=18.0344(6) \AA, c=20.8102(8) \AA$, $\mathrm{V}=3516.0(2) \AA^{3}, \mathrm{Z}=4, \mathrm{D}($ calcd $)=1.271 \mathrm{~g} \mathrm{~cm}^{-3}, \mu(\mathrm{MoK} \alpha)=1.082 \mathrm{~mm}^{-1}, \mathrm{~F}(000)=1424$. Crystal size $0.02 \times 0.03 \times 0.25 \mathrm{~mm}^{3}, \lambda=1.5416 \AA$ A $\theta=3.243$ to $68.255^{\circ}$, index ranges $-11 \leq$ $h \leq 10,-21 \leq k \leq 21,-25 \leq l \leq 25$. Reflections collected/independent: 56559/6400 [R(int) $=0.0653$ ]. Non-hydrogen atoms were refined with anisotropic displacement parameters. The positions of the O-bonded hydrogen atoms were found in a $\Delta \mathrm{F}$ map and were refined isotropically. Carbon-bonded $\mathrm{H}$-atoms were positioned geometrically and were allowed to ride on their parent atoms, with $\mathrm{Uiso}(\mathrm{H})=1.5 \mathrm{Ueq}$ for the methyl groups and $1.2 \mathrm{Ueq}$ for the remaining $C$ atoms. Parameters refined 452; Goodness-of-fit on $F^{2} 1.062$, final $\mathrm{R}$ indices $[\mathrm{I}>2 \sigma(\mathrm{I})] \mathrm{R} 1=0.0351, \mathrm{wR} 2=0.0752, \mathrm{R}$ indices (all data) $\mathrm{R} 1=0.0456, \mathrm{wR} 2=0.0808$. Absolute structure parameter $\mathrm{x}=0.007(9) . \Delta \rho \max / \min 0.17$ and -0.23 e. $\AA^{-3}$. CCDC No. 2096677.

$(S)-2 \bullet(R, R)-$ TADDOL complex; colorless crystals; m.p. $=158.1-158.6{ }^{\circ} \mathrm{C}$; diastereomeric excess [of (S)-2]: >99\%; $\left([\alpha]_{\mathrm{D}}^{20}=+38.8\right.$ (c 1.0, $\left.\left.\mathrm{CHCl}_{3}\right)\right)$; CSP-HPLC conditions: CHIRALCEL OD-H, hexane/2-propanol = 90:10, $0.5 \mathrm{~mL} / \mathrm{min}$, retention time [for $(S)-2]=$ $74.3 \mathrm{~min}$; Anal. Calcd for $\mathrm{C}_{42} \mathrm{H}_{41} \mathrm{O}_{6} \mathrm{P}: \mathrm{C}, 74.98 ; \mathrm{H}, 6.14$; Found: $\mathrm{C}, 75.11 ; \mathrm{H}, 6.20$.

Crystal data: formula $\mathrm{C}_{42} \mathrm{H}_{41} \mathrm{O}_{6} \mathrm{P}, \mathrm{M}_{\mathrm{W}}=672.72$, crystal system triclinic, space group $P$ 1. Unit cell dimensions: $a=8.538(2) \AA, b=18.162(3) \AA, c=23.912(4) \AA, \alpha=98.12(1)^{\circ}$, $\beta=99.85(1)^{\circ}, \gamma=100.28(2)^{\circ}, \mathrm{V}=3537.8(12) \mathrm{A}^{3}, \mathrm{Z}=4, \mathrm{D}($ calcd $)=1.263 \mathrm{~g} \mathrm{~cm}^{-3}$, absorption coefficient $\mu(\mathrm{MoK} \alpha)=0.126 \mathrm{~mm}^{-1}, \mathrm{~F}(000)=1424$. Crystal size $0.02 \times 0.03 \times 0.4 \mathrm{~mm}^{3}$, $\lambda=0.71073 \AA, \theta$ range for data collection 2.619 to $29.795^{\circ}$; index ranges $-11 \leq h \leq 11,-24$ $\leq k \leq 13,-29 \leq l \leq 32$. Reflections collected/independent $[\mathrm{R}(\mathrm{int})=0.1153]$ /observed $[\mathrm{I}>2 \sigma(\mathrm{I})] 26584 / 19964 / 3973$, completeness to $\theta=25.242^{\circ} 99.9 \%$. The crystals diffracted poorly and the data-to-parameter ratio was very low at 4.9. Non-hydrogen atoms, with the exception of $\mathrm{P}$ atoms, were refined with isotropic displacement parameters. The model was refined with four disordered methylene $\mathrm{C}$ atoms, and $8 \mathrm{C}-\mathrm{C}$ bonds were constrained to $1.53 \AA$. Hydrogen atoms were positioned geometrically and retr allowed to ride on their parent atoms, with Uiso(H) $=1.5 \mathrm{Ueq}$ for the hydroxyl and methyl groups and 1.2 Ueq for the remaining C atoms. Data/restraints/parameters 19964/11/812; Goodness-of-fit on $\mathrm{F}^{2}$ 0.661; Final R indices $[\mathrm{I}>2 \sigma(\mathrm{I})] \mathrm{R} 1=0.0827, \mathrm{wR} 2=0.1572$; R indices (all data) R1 = 0.3070, 
$\mathrm{wR} 2=0.2069 ;$ absolute structure parameter $\mathrm{x}=-0.1(2)$. Largest difference peak and hole 0.50 and -0.37 e. Å-3. CCDC No. 2096678.

(R)-1-phenyl-phosphorinenone 1-oxides (®-2); 99.9\% e.e.; colorless crystals; m.p. = $128.5-129.1{ }^{\circ} \mathrm{C} ;\left([\alpha]_{\mathrm{D}}^{20}=-284.1\left(c 1.03, \mathrm{CHCl}_{3}\right)\right) ; \mathrm{R}_{\mathrm{f}}=0.33\left(\mathrm{CHCl}_{3} / \mathrm{THF}=10: 1\right) ;$ Anal. Calcd for $\mathrm{C}_{11} \mathrm{H}_{11} \mathrm{O}_{2} \mathrm{P}: \mathrm{C}, 64.08 ; \mathrm{H}, 5.38$; Found: $\mathrm{C}, 64.27 ; \mathrm{H}, 5.43$.

(S)-1-phenyl-phosphorinenone 1-oxides ((S)-2); $99.1 \%$ e.e.; colorless crystals; m.p. = $126.7-127.9^{\circ} \mathrm{C} ;\left([\alpha]_{\mathrm{D}}^{20}=+278.3\left(c 1.1, \mathrm{CHCl}_{3}\right)\right) ; \mathrm{R}_{\mathrm{f}}=0.33\left(\mathrm{CHCl}_{3} / \mathrm{THF}=10: 1\right)$; Anal. Calcd for $\mathrm{C}_{11} \mathrm{H}_{11} \mathrm{O}_{2} \mathrm{P}: \mathrm{C}, 64.08 ; \mathrm{H}, 5.38$; Found: $\mathrm{C}, 64.14 ; \mathrm{H}, 5.41$.

\subsection{Chemical Correlation of the Absolute Configurations of 1-Phenylphosphin-2-en-4-one 1-Sulfide (R)-1}

An amount of $0.2 \mathrm{~g}(0.1 \mathrm{mmol})$ of ( $R$ )-1-phenyl-phosphin-2-en-4-one 1-oxide dissolved in $5 \mathrm{~mL}$ of dry toluene was placed in a $20 \mathrm{~mL}$ round-bottom flask. The solution was degassed and placed under an argon atmosphere. An amount of $0.185 \mathrm{~mL}(0.15 \mathrm{mmol})$ of $\mathrm{PhSiH}_{3}$ was added to the solution, and the reaction mixture was stirred at $\mathrm{rt}$ for 5 days. After this time, $0.03 \mathrm{~g}(0.1 \mathrm{mmol})$ of $\mathrm{S}_{8}$ was added to the solution, and the reaction mixture was stirred for $2 \mathrm{~h}$. At the end of the reaction, the mixture was concentrated, and the crude product was passed through a silica gel column using hexane/THF (10:1) as the eluent to yield $0.022 \mathrm{~g}$ (11\% overall yield after two steps) of 1-phenylphosphin-2-en-4-one 1-sulfide $(R)-1$ as a colorless oil; $\left([\alpha]_{\mathrm{D}}^{20}=-88.77\left(c 1.1, \mathrm{CHCl}_{3}\right)\right.$ for e.e. $\left.=99 \%\right) ; \mathrm{R}_{\mathrm{f}}=0.36$ (hexane $/ \mathrm{THF}$ = 6:1); CSP-HPLC conditions: CHIRALCEL OJ-H, hexane $/ 2$-propanol (95:5), $1 \mathrm{~mL} / \mathrm{min}$, retention time $=72 \mathrm{~min} .{ }^{1} \mathrm{H}$ NMR $\left(500 \mathrm{MHz}, \mathrm{CDCl}_{3}\right): \delta 7.96-7.89(\mathrm{~m}, 2 \mathrm{H}), 7.66-7.61(\mathrm{~m}$, $1 \mathrm{H}), 7.61-7.55(\mathrm{~m}, 2 \mathrm{H}), 7.05-6.95(\mathrm{~m}, 1 \mathrm{H}), 6.63(\mathrm{dd}, J=12.5$ and $34.5 \mathrm{~Hz}, 1 \mathrm{H}), 3.30(\mathrm{tdd}$, $J=4.6,12.2$ and $16.5 \mathrm{~Hz}, 1 \mathrm{H}), 2.95-2.73(\mathrm{~m}, 2 \mathrm{H}), 2.62-2.49(\mathrm{~m}, 1 \mathrm{H}) .{ }^{13} \mathrm{C} \mathrm{NMR}(126 \mathrm{MHz}$, $\left.\mathrm{CDCl}_{3}\right): \delta 195.6(\mathrm{~d}, J=13.6 \mathrm{~Hz}, \mathrm{C}=\mathrm{O}), 139.3(\mathrm{~d}, J=3.6 \mathrm{~Hz}, \mathrm{C} 3), 139.2(\mathrm{~d}, J=68.2 \mathrm{~Hz}, \mathrm{C} 2)$, $132.7\left(\mathrm{~d}, J=3.6 \mathrm{~Hz}, \mathrm{C}_{\text {para }}\right), 131.1\left(\mathrm{~d}, J=11.8 \mathrm{~Hz}, \mathrm{C}_{\text {ortho }}\right), 129.6\left(\mathrm{~d}, J=85.7 \mathrm{~Hz}, \mathrm{C}_{\mathrm{ipso}}\right), 129.1$ $\left(\mathrm{d}, J=11.8 \mathrm{~Hz}, \mathrm{C}_{\text {meta }}\right), 34.0(\mathrm{~d}, J=7.3 \mathrm{~Hz}, \mathrm{C} 5), 31.3(\mathrm{~d}, J=55.4 \mathrm{~Hz}, \mathrm{C} 6) .{ }^{31} \mathrm{P}$ NMR $(202 \mathrm{MHz}$, $\mathrm{CDCl}_{3}$ ): $\delta 21.3 \mathrm{ppm}$. GCMS (EI, $\left.70 \mathrm{eV}\right) \mathrm{m} / \mathrm{z}=223.05$ (13), 222.05 (100), 190.10 (14), 189.10 (86), 171.10165 .05 (10), (12), 143.15 (12), 142.15 (96), 141.15 (18), 140.05 (50), 134.10 (22), 133.10 (50), 131.10 (20), 109.10 (11), 108.10 (28), 107.10 (69), 105.15 (24), 103.10 (18), 91.10 (10), 83.05 (12), 81.05 (11). Anal. Calcd for $\mathrm{C}_{11} \mathrm{H}_{11} \mathrm{OPS}$ : C, 59.45; H, 4.99. Found: C, 59.15; $\mathrm{H}, 4.78$.

\section{Conclusions}

The developed resolution protocol provides ready and efficient access to gram quantities of both enantiomers of 1-phenylphosphin-2-en-4-one 1-oxide (2) through the separation of their molecular crystalline complexes with $(R, R)$-TADDOL. The recovery of the resolved enantiomers of $\mathbf{2}$ by flash column chromatography offers a convenient method for obtaining enantiomerically pure phosphine oxides $(R)-2(59 \%$ yield, $99.9 \%$ e.e.) and $(S)-2$ (62\% yield, $>99 \%$ e.e.) as well as for recovering $(R, R)$-TADDOL in a nearly quantitatively yield. The X-ray crystallography revealed that in the $(R)-\mathbf{2} \bullet(R, R)$-TADDOL complex, the P-phenyl substituent occupies a pseudoequatorial position, whereas in the $(S)-\mathbf{2} \bullet(R, R)$ TADDOL complex, it appears in both the pseudoequatorial and pseudoaxial positions in four symmetrically independent molecules. The resolved $(R)-2$ was used to conduct a chemical correlation to assign the absolute configuration of a recently described (-)-1phenylphosphin-2-en-4-one 1-sulfide (1) by chemical correlation. In addition, an attempted stereoretentive reduction of $(R)-2$ by $\mathrm{PhSiH}_{3}$ at $60{ }^{\circ} \mathrm{C}$ revealed an unexpectedly low barrier for the P-inversion of 1-phenylphosphin-2-en-4-one.

The analysis of the structural data that have been published for the TADDOL molecule, which is frequently used as a receptor in racemate resolutions, so far showed that it is capable of adpating its conformation to the presence of opposite enantiomers of a ligand molecule. These changes enable the best steric adjustment of the receptor $\bullet$ ligand system, increasing the strength of hydrogen bonding to TADDOL in the solid. On the other hand, when the enantiomeric molecules are also conformationally flexible, they also adjust their 
shape to fit the TADDOL binding site. Experimental evidence was obtained from the crystallographic studies of the pair of enantiomeric TADDOL complexes analyzed in this work and two other analyses that were performed earlier.

Supplementary Materials: Table S1: Data search in the Cambridge Structural Database (CSD ver. $5.42)$ for the occurrence of $(R, R)$-TADDOL complexes with various ligands [21,22,26,27,31,36-56].

Author Contributions: Conceptualization, K.M.P.; investigation, E.Ł., A.W., A.E.K. and H.M.; supervision, K.M.P.; writing—original draft, E.Ł.; writing—review and editing, E.Ł., A.E.K. and K.M.P. All authors have read and agreed to the published version of the manuscript.

Funding: Financial support from the Ministry of Science and Higher Education (Research grant No. N N204 445240) is gratefully acknowledged.

Data Availability Statement: The data presented in this study are openly available.

Acknowledgments: The authors wish to thank Sławomir Frynas for the help in preparation of $(R, R)$-TADDOL.

Conflicts of Interest: The authors declare no conflict of interest.

\section{References}

1. Grabulosa, A. P-Stereogenic Ligands in Enantioselective Catalysis, 1st ed.; RSC Publishing: Cambridge, UK, 2011 ; pp. 1-501.

2. Kamer, P.C.J.; van Leeuwen, P.W.N.M. Phosphorous(III) Ligands in Homogeneous Catalysis: Design and Synthesis; John Wiley \& Sons, Ltd.: West Sussex, UK, 2012.

3. Tang, W.; Zhang, X. New Chiral Phosphorus Ligands for Enantioselective Hydrogenation. Chem. Rev. 2003, 103, 3029-3069. [CrossRef]

4. de Vries, J.G.; Elsevier, C.J. Handbook of Homogeneous Hydrogenation; Wiley-VCH: Weinheim, Germany, 2006; Volumes 1-3.

5. Ni, H.; Chan, W.-L.; Lu, Y. Phosphine-Catalyzed Asymmetric Organic Reactions. Chem. Rev. 2018, 118, 9344-9411. [CrossRef]

6. Kobayashi, S.; Shiraishi, N.; Lam, W.W.-L.; Manabe, K. Asymmetric synthesis of proline and pipecolic acid phosphorous analogues using enantioselective deprotonation-carboxylation reactions. Tetrahedron Lett. 2001, 42, 7303-7306. [CrossRef]

7. Harvey, J.S.; Malcolmson, S.J.; Dunne, K.S.; Meek, S.J.; Thompson, A.L.; Schrock, R.R.; Hoveyda, A.H.; Gouverneur, V. Enantioselective Synthesis of P-Stereogenic Phosphinates and Phosphine Oxides by Molybdenum-Catalyzed Asymmetric Ring-Closing Metathesis. Angew. Chem. Int. Ed. 2009, 48, 762-766. [CrossRef]

8. Zheng, Y.; Guo, L.; Zi, W. Enantioselective and Regioselective Hydroetherification of Alkynes by Gold-Catalyzed Desymmetrization of Prochiral Phenols with P-Stereogenic Centers. Org. Lett. 2018, 20, 7039-7043. [CrossRef]

9. Łastawiecka, E.; Frynas, S.; Pietrusiewicz, K.M. Desymmetrization Approach to the Synthesis of Optically Active P-Stereogenic Phosphin-2-en-4-ones. J. Org. Chem 2021, 86, 6195-6206. [CrossRef] [PubMed]

10. Mohar, B.; Čusak, A.; Modec, B.; Stephan, M. P-Stereogenic Phospholanes or Phosphorinanes from o-Biarylylphosphines: Two Bridges Not Too Far. J. Org. Chem. 2013, 78, 4665-4673. [CrossRef] [PubMed]

11. Ostermeier, M.; Prieß, J.; Helmchen, G. Mono-and Bidentate Phosphinanes-New Chiral Ligands and Their Application in Catalytic Asymmetric Hydrogenations. Angew. Chem. Int. Ed. 2002, 41, 612-614. [CrossRef]

12. Yan, Y.; Zhang, X. Six-membered bis(azaphosphorinane), readily available ligand for highly enantioselective asymmetric hydrogenations. Tetrahedron Lett. 2006, 47, 1567-1569. [CrossRef]

13. Doro, F.; Lutz, M.; Reek, J.N.H.; Spek, A.L.; van Leeuwen, P.W.N.M. P-Chirogenic Benzo-Fused Phenoxaphosphane: Synthesis, Resolution and Study of the Stereochemical Properties of the Corresponding Palladium Complexes. Eur. J. Inorg. Chem. 2008, 8 , 1309-1317. [CrossRef]

14. Breit, B.; Fuchs, E. Chiral phosphabarrelene ligands: Synthesis and evaluation in rhodium-catalyzed asymmetric hydrogenation. Synthesis 2006, 13, 2121-2128. [CrossRef]

15. Hopewell, J.; Jankowski, P.; McMullin, C.L.; Orpen, A.G.; Pringle, P.G. Subtleties in asymmetric catalyst structure: The resolution of a 6-phospha-2,4,8-trioxaadamantane and its applications in asymmetric hydrogenation catalysis. Chem. Commun. 2010, 46, 100-102. [CrossRef] [PubMed]

16. Ujj, V.; Kerenyi, A.; Laki, A.; Fogassy, E.; Keglevich, G. Optically Active 6-Membered P-Heterocycles: 1-Phenyl-1,2- Dihydrophosphinine Oxide and 1-Phenyl-3-Diphenylphosphinoyl1,2,3,6-Tetrahydrophosphinine Oxide. Lett. Org. Chem. 2010, 7, 110-113. [CrossRef]

17. Bagi, P.; Laki, A.; Keglevich, G. Preparation of Optically Active Six-Membered P-Heterocycles: A 3-Phosphabicyclo[3.1.0] hexane 3-oxide, a 1,2-Dihydrophosphinine 1-oxide, and a 1,2,3,6- Tetrahydrophosphinine 1-oxide. Heteroat. Chem. 2013, 24, 179-186. [CrossRef]

18. Pietrusiewicz, K.M.; Koprowski, M.; Drzazga, Z.; Parcheta, R.; Łastawiecka, E.; Demchuk, O.M.; Justyniak, I. Efficient Oxidative Resolution of 1-Phenylphosphol-2-Ene and Diels-Alder Synthesis of Enantiopure Bicyclic and Tricyclic P-Stereogenic C-P Heterocycles. Symmetry 2020, 12, 346. [CrossRef] 
19. Pietrusiewicz, K.M.; Zablocka, M. Preparation of Scalemic P-Chiral Phosphines and Their Derivatives. Chem. Rev. 1994, 94, 1375-1411. [CrossRef]

20. Holt, J.; Maj, A.M.; Schudde, E.P.; Pietrusiewicz, K.M.; Sieron, L.; Wieczorek, W.; Jerphagnon, T.; Arends, I.W.C.E.; Hanefeld, U.; Minnaard, A.J. On the Resolution of Secondary Phosphine Oxides via Diastereomeric Complex Formation: The Case of tert-Butylphenylphosphine Oxide. Synthesis 2009, 12, 2061-2065.

21. Novák, T.; Schindler, J.; Ujj, V.; Czugler, M.; Fogassy, E.; Keglevich, G. Resolution of 3-methyl-3-phospholene 1-oxides by molecular complex formation with TADDOL derivatives. Tetrahedron Asymmetry 2006, 17, 2599-2602. [CrossRef]

22. Novák, T.; Ujj, V.; Schindler, J.; Czugler, M.; Kubinyi, M.; Mayer, Z.A.; Fogassy, E.; Keglevich, G. Resolution of 1-substituted-3methyl-3-phospholene 1-oxides by molecular complex formation with TADDOL derivatives. Tetrahedron Asymmetry 2007, 18, 2965-2972. [CrossRef]

23. Bagi, P.; Fekete, A.; Kállay, M.; Hessz, D.; Kubinyi, M.; Holczbauer, T.; Czugler, M.; Fogassy, E.; Keglevich, G. A Case Study on the Resolution of the 1-i-Butyl-3-methyl-3-phospholene 1-Oxide via Diastereomeric Complex Formation Using TADDOL Derivatives and via Diastereomeric Coordination Complexes Formed from the Calcium Salts of $\mathrm{O}, \mathrm{O}^{\prime}$-Diaroyl-(2R,3R)-Tartaric Acids. Heteroat. Chem. 2014, 26, 79-90. [CrossRef]

24. Quin, L.D. For earlier observations of axially positioned P-phenyl groups in phosphinane rings. In The Heterocyclic Chemistry of Phosphorus: Systems Based on the Phosphorus-Carbon Bond; John Wiley \& Sons: New York, NY, USA, 1981; Chapter 8; pp. 368-370.

25. Spackman, M.A.; Jayatilaka, D. Hirshfeld surface analysis. CrystEngComm 2009, 10, 1081-1084. [CrossRef]

26. Bathori, N.B.; Nassimbeni, L.R. Selectivity and Enantiomeric Resolution in Inclusion Chemistry: A Systematic Study of Chiral Discrimination through Crystallization. Cryst. Growth Des. 2010, 10, 1782-1787. [CrossRef]

27. Zimmerman, H.E.; Alabugin, I.V.; Smolenskaya, V.N. Experimental and Theoretical Host-Guest Photochemistry; Control of Reactivity with Host Variation and Theoretical Treatment with a Stress Shaped Reaction Cavity; Mechanistic and Exploratory Organic Photochemistry. Tetrahedron 2000, 56, 6821-6831. [CrossRef]

28. Marsi, K.L. Phenylsilane Reduction of Phosphine Oxides with Complete Stereospecificity. J. Org. Chem. 1974, 39, 265-267. [CrossRef]

29. Horner, L.; Winkler, H. Phosphororganische Verbindungen XXXIX Konfigurationsbeziehungen zwischen optisch aktiven, Phosphororganischen Verbindungen. Tetrahedron Lett. 1964, 5, 175-179. [CrossRef]

30. Holz, J.; Jiao, H.; Gandelman, M.; Börner, A. About the Inversion Barriers of P-Chirogenic Triaryl-Substituted Phosphanes. Eur. J. Org. Chem. 2018, 23, 2984-2994. [CrossRef]

31. Du, H.; Zhao, D.; Ding, K. Enantioselective Catalysis of the Hetero-Diels-Alder Reaction between Brassard's Diene and Aldehydes by Hydrogen-Bonding Activation: A One-Step Synthesis of (S)-(+)-Dihydrokawain. Chem. Eur. J. 2004, 10, 5964-5970. [CrossRef] [PubMed]

32. CrysAlisPro, Version 1.171.36.20 (Release 27-06-2012); Agilent Technologies Poland: Warsaw, Poland, 2012.

33. Sheldrick, G.M. SHELXS-86-A program for automatic solution of crystal structures. Acta. Cryst. 1990, A46, 467-473. [CrossRef]

34. Sheldrick, G.M. SHELXT-Integrated space-group and crystal-structure determination. Acta Cryst. 2015, A71, 3-8. [CrossRef]

35. Sheldrick, G.M. Crystal structure refinement with SHELXL. Acta Cryst. 2015, C71, 3-8.

36. Toda, F.; Tanaka, K.; Ootani, M.; Hayashi, A.; Miyahara, I.; Hirotsu, K. Structure study of host-guest molecular association in solution and in the solid state. J. Chem. Soc. Chem. Commun. 1993, 18, 1413-1415. [CrossRef]

37. Urbańczyk-Lipkowska, Z.; Fukuda, N.; Tanaka, K. Resolution of $\alpha$-aminolactams by inclusion complexation with chiral host compounds. Tetrahedron Asymmetry 2017, 18, 1254-1256. [CrossRef]

38. Lipkowska, Z. CCDC 643248: Experimental Crystal Structure Determination. In CSD Communication; 2017. Available online: https:/ / search.datacite.org/works / 10.5517/ccdc.csd.ccplbyj (accessed on 20 October 2021).

39. Tanaka, K.; Kuchiki, D.; Caira, M.R. Optical resolution of medium-size lactones by inclusion crystallization with optically active host compounds: Remarkable odd-even effects on the chiral recognition. Tetrahedron Asymmetry 2006, 17, 1678-1683. [CrossRef]

40. Tanaka, K.; Toda, F.; Mochizuki, E.; Yasui, N.; Kai, Y.; Miyahara, I.; Hirotsu, K. Enantioselective Single-Crystal-to-Single-Crystal Photodimerization of Coumarin and Thiocoumarin in Inclusion Complexes with Chiral Host Compounds. Angew. Chem. Int. Ed. 1999, 38, 3523-3525. [CrossRef]

41. Nassimbeni, L.R.; Niven, M.L.; Tanaka, K.; Toda, F. On the optical resolution of bicyclic enones through host-guest complex formation: The crystallographic result. J. Crystallogr. Spectrosc. Research 1991, 21, 451-457. [CrossRef]

42. Toda, F.; Tanaka, K.; Marks, D.; Goldberg, I. Optical resolution of bicyclo[2.2.1]heptanone, bicyclo[2.2.2]octanone, and bicyclo[3.2.1] octanone derivatives by inclusion complexation with optically active host compounds. J. Org. Chem. 1991, 56, 7332-7335. [CrossRef]

43. Takemoto, Y.; Kuraoka, S.; Hamaue, N.; Aoe, K.; Hiramatsu, H.; Iwata, C. Enantioselective Cu-catalyzed 1,4-addition of Me3Al to a 4,4-disubstituted cyclohexa-2,5-dienone. Tetrahedron 1996, 52, 14177-14188. [CrossRef]

44. Lavy, T.; Sheynin, Y.; Kaftory, M. The effects of space formed by host molecules in inclusion compounds on the homogeneity/heterogeneity of the photoreaction in the solid state. Eur. J. Org. Chem. 2004, 23, 4802-4808. [CrossRef]

45. Urbańczyk-Lipkowska, Z.; Yoshizawa, K.; Toyota, S.; Toda, F. Easy isolation of the enol form of acetylacetone as an inclusion complex with host compounds. CrystEngComm 2003, 5, 114-116. [CrossRef]

46. Ghazali, N.F.; Ferreira, F.C.; White, A.J.P.; Livingston, A.G. Enantiomer separation by enantioselective inclusion complexationorganic solvent nanofiltration. Tetrahedron Asymmetry 2006, 17, 1846-1852. [CrossRef] 
47. Olszewska, T.; Pyszno, A.; Milewska, M.J.; Gdaniec, M.; Polonski, T. Thioamides and selenoamides with chirality solely due to hindered rotation about the $\mathrm{C}-\mathrm{N}$ bond: Enantioselective complexation with optically active hosts. Tetrahedron Asymmetry 2005, 16, 3711-3717. [CrossRef]

48. Olszewska, T.; Milewska „, M.J.; Gdaniec, M.; Małuszyńska, H.; Połoński, T. Asymmetric Transformation of N-Nitrosamines by Inclusion Crystallization with Optically Active Hosts. J. Org. Chem. 2001, 66, 501-506. [CrossRef] [PubMed]

49. Olszewska, T.; Sikorski, A.; Herman, A.; Połoński, T. Helicity discrimination in N,N'-dibenzoyl-1,2,3,4,7,8,9,10-octahydro- 1,10phenanthrolines and their thiono- and selenocarbonyl analogues by inclusion complexation with chiral diols. Org. Biomol. Chem. 2013, 11, 7522-7529. [CrossRef]

50. Toda, F.; Tanaka, K.; Foces-Foces, C.; Infantes, L.; Claramunt, R.M.; Lopez, C.; Elguero, J. Host-guest chemistry. The structure and proton disorder of the three-component crystal formed by 3(5)-methyl-4-nitropyrazole, (R, R)-(-)-trans-4,5-bis (hydroxydiphenylmethyl)-2,2-dimethyl-1,3-dioxolane and toluene. J. Phys. Org. Chem. 1996, 9, 611-618. [CrossRef]

51. Hu, X.; Shan, Z.; Li, W. Second example for the heterocomplexation of chiral diols and complete disproportionation of enantiomers for non-racemic 2,3-O-cyclohexylidene-1,1,4,4-tetraphenylthreitols. J. Fluor. Chem. 2010, 131, 505-509. [CrossRef]

52. Zhu, J.; Zhou, Z.-Y.; Fu, F.-M.; Deng, J.-G.; Mi, A.-Q.; Jiang, Y.-Z.; Chau, T.-Y. Crystal structure analysis of (R)-ethyl-2-pyridine sulfoxide and (4R,5R)-TADDOL clathrate [C7H9NOS.C31H30O4]. In Gaodeng Xuexiao Huaxue Xuebao; 1999; Volume 20 , p. 1081.

53. Bourne, S.A.; Oom, B.M.; Toda, F. Kinetics of desolvation from crystalline inclusion compounds of a diol host with methanol and ethanol. J. Chem. Soc. Perkin Trans. 2 1997, 3, 585-588. [CrossRef]

54. Goldberg, I.; Stein, Z.; Weber, E.; Dorpinghaus, N.; Franken, S. Exploring the inclusion properties of new clathrate hosts derived from tartaric acid. X-ray structural characterization of the free ligands and their selective interaction modes with alkylamine guests. J. Chem. Soc. Perkin Trans. 2 1990, 16, 953-963. [CrossRef]

55. Barton, B.; Hosten, E.C.; Jooste, D.V. Comparative investigation of the inclusion preferences of optically pure versus racemic TADDOL hosts for pyridine and isomeric methylpyridine guests. Tetrahedron 2017, 73, 2662-2673. [CrossRef]

56. Beck, A.K.; Bastani, B.; Plattner, D.A.; Petter, W.; Seebach, D.; Braunschweiger, H.; Gysi, P.; La Vecchia, L. Grossansätze zur Herstellung von $\alpha, \alpha, \alpha^{\prime}, \alpha^{\prime}$-tetraaryl-1,3-dioxolan-4,5-dimethanolen(TADDOLe): Nützliche hilfsstoffe für die EPC-Synthese und ihre struktur im Festkörper. Chimia 1991, 45, 238-244. 